\title{
Philippine mossy forest stick insects: first record of the genus Otraleus Günther, 1935 in the country, with four new species, and the new genus Capuyanus gen. nov. (Phasmida, Diapheromeridae, Necrosciinae)
}

\author{
Joachim BRESSEEL ${ }^{1, *}$ \& Jérôme CONSTANT ${ }^{2}$ \\ 1,2 Royal Belgian Institute of Natural Sciences, O.D. Phylogeny and Taxonomy, Entomology, \\ Vautierstraat 29, B-1000 Brussels, Belgium. \\ *Corresponding author: joachimbresseel@gmail.com \\ ${ }^{2}$ Email: jerome.constant@,naturalsciences.be \\ ${ }^{1}$ urn:1sid:zoobank.org:author:3C4EF358-9716-46F0-8575-26BE1EDE4349 \\ ${ }^{2}$ urn:1sid:zoobank.org:author:6E6072A1-9415-4C8D-8E60-2504444DB290
}

\begin{abstract}
The genus Otraleus Günther, 1935 is recorded from the Philippines for the first time. Four new species, Otraleus bellemansae sp. nov., O. applai sp. nov., O. christianae sp. nov. and $O$. elizabethae sp. nov., are described from the highlands of Northwestern Luzon. The characters allowing separation from O. hypsimelathrus Günther, 1935 and O. labanrataensis Soew-Choen, 2016, are given. A new genus closely related to Otraleus, Capuyanus gen. nov., is described with a single species, C. magwilangi sp. nov., as type-species. An identification key and distribution maps are provided for all species.
\end{abstract}

Keywords. Cordillera Administrative Region, Phasmatodea, cloud forest, Philippines, orophilous species.

Bresseel J. \& Constant J. 2017. Philippine mossy forest stick insects: first record of the genus Otraleus Günther, 1935 in the country, with four new species, and the new genus Capuyanus gen. nov. (Phasmida, Diapheromeridae, Necrosciinae). European Journal of Taxonomy 265: 1-31. http://dx.doi.org/10.5852/ejt.2017.265

\section{Introduction}

The genus Otraleus was established by Günther (1935) to accommodate Otraleus hypsimelathrus Günther, 1935. The species was described based on a single male collected by the late German entomologist and ornithologist Gerd Herrmann Heinrich (1896-1984) in the mossy forest of the Latimodjong Mountains, Sulawesi (Weems 1986). Since the original description of $O$. hypsimelathrus, the genus remained unaltered until recently, when a new species from Sabah, Borneo, O. labanrataensis Soew-Choen, 2016, was described (Seow-Choen 2016). The female of O. hypsimelathrus still remains unknown.

Study of recent material collected in the mossy forests between 1800 and $2200 \mathrm{~m}$ a.s.1., in northwestern Luzon (Mountain, Ifugao and Benguet Provinces), revealed five new species of Otraleus-like phasmids. Four of them belong to Otraleus while the fifth one represents a new genus close to Otraleus, which is here described as Capuyanus gen. nov. 
These high altitude forests in Luzon are cold and wet environments due to low-level clouds that submerge the forest in a constant mist. The main vegetation consists of small trees densely covered with mosses, ferns, lichens and orchids. Phasmids occurring in mossy forests are poorly studied and the species collected by Gerd Heinrich in 1930-1932 are some of the few that are described from this habitat in South-East Asia. The distance between the two records of the genus exceeds $2000 \mathrm{~km}$, mirroring our poor knowledge of Phasmida species in these habitats. Most stick insects occurring in mossy forests are small and incapable of flight.

The present paper aims to describe the new taxa and provide a key allowing their identification.

\section{Material and methods}

Due to their nocturnal behaviour, the specimens at hand for the present study, were collected at night. A light-weight and water-proof head torch, Petzl MYO RXP, was used during the search of the vegetation. The specimens caught in the wild were euthanized with ethyl acetate fumes. The specimens were then stored in airtight plastic "zip" bags in wood chips (used in rodent cages) and sprinkled with ethyl acetate (EtOAc) to prevent rotting and mould, and to keep the specimens flexible. The bags were then frozen on arrival and the specimens were mounted and labelled later on.

Morphological observations were made with a Leica MZ8 stereo microscope. Pictures were taken with a Canon EOS 700 D camera with a Sigma DG Macro lens and optimized with Photoshop CS3.

\section{Acronyms used for the collections}

RBINS = Royal Belgian Institute of Natural Sciences, Brussels, Belgium

UPLB = University of the Philippines Los Baños, Los Baños, Philippines

MFNB = Museum für Naturkunde, Berlin, Germany

\section{Results}

Family Diapheromeridae Kirby, 1904

Subfamily Necrosciinae Brunner von Wattenwyl, 1893

Tribe Necrosciini Brunner von Wattenwyl, 1893

Genus Otraleus Günther, 1935

Otraleus Günther, 1935: 28 (description), pl. 2, fig. 18 (illustration).

Otraleus - Bradley \& Galil 1977: 182 (list). - Hennemann 1998: 122 (type data). — Bragg 2001: 639 (type data). - Zompro 2004: 316 (type data); 2005: 267 (type data). — Otte \& Brock 2005: 242 (type data). - Seow-Choen 2016: 199 (description, notes on holotype).

\section{Type species}

Otraleus hypsimelathrus Günther, 1935, by original designation.

\section{Diagnosis}

Small and cryptically shaped Necrosciinae, body surface brown to green, apterous to brachypterous. Head longer than wide, antennae long and filiform, strongly projecting over apex of abdomen. Most species have well developed posterolateral lobes on several abdominal segments. Subgenital plate in females laterally compressed, not reaching apex of abdomen. Legs smooth and unarmed, claws small. Cerci of males surpassing apex of abdomen. 
The genus Otraleus Günther, 1935 can be distinguished from other genera in Necrosciinae by the combination of the following characters:

1. Legs long in relation to body length, all carinae developed and unarmed.

2. Abdominal segments with lobes or extensions postero-laterally on at least terga III-VII in females.

3. Body length not exceeding $50 \mathrm{~mm}$ in males and $55 \mathrm{~mm}$ in females.

4. Subgenital plate in females not surpassing anal segment and laterally flattened at the base.

5. Anal segment notched posteriorly and rounded postero-laterally.

6. Praeopercular organ absent in females.

7. Vomer well developed, elongated, flattened and strongly tapered.

The exact systematic position and the most closely related genera are still unknown. The Necrosciinae of the Philippines and Sulawesi are poorly studied and more material is needed to resolve its systematic position.

\section{Species included and distribution}

Otraleus applai sp. nov. (Philippines: Luzon: Mountain Province and Benguet Province)

Otraleus bellemansae sp. nov. (Philippines: Luzon: Mountain Province)

Otraleus christianae sp. nov. (Philippines: Luzon: Mountain Province and Ifugao Province)

Otraleus elizabethae sp. nov. (Philippines: Luzon: Benguet Province)

Otraleus hypsimelathrus Günther, 1935 (Indonesia: Sulawesi: Mt Latimodjong)

Otraleus labanrataensis Seow-Choen, 2016 (Malaysia: Sabah: Mt Kinabalu)

\section{Note on Otraleus hypsimelathrus Günther, 1935}

Otraleus hypsimelathrus Günther, 1935: 28 (description), pl. 2, fig. 18 (dorsal aspect of habitus).

Otraleus hypsimelathrus - Günther 1938: 59 (list). — Hennemann 1998: 122 (list). — Zompro 2005: 267 (type data). - Otte \& Brock 2005: 242 (type data). - Seow-Choen 2016: 199 (notes on holotype).

To supplement Günther's (1935) original description, we provide illustrations of the holotype along with a distribution map for the species which is so far known from a single location in Sulawesi (Fig. 1). Currently only the male is known.

Males of $O$. hypsimelathrus Günther, 1935 can be separated from the four newly described Philippine species of Otraleus by the following combination of characters:

1. Abdominal terga II-VIII with definite lobes postero-laterally.

2. Ventral portion of thorax black.

3. Apterous.

4. Mesonotum, median segment and abdominal terga at best with an indefinite hump posteromedially.

Key to the Philippine species of Otraleus and Capuyanus gen. nov.

1. Abdominal terga without postero-lateral lobes; females with subgenital plate strongly tapered, projecting over apex of tergum X; males with swollen and conical thornpads on anal segment (genus Capuyanus)

Capuyanus magwilangi sp. nov.

- Abdominal terga with postero-lateral lobes; females with subgenital plate not strongly tapered, not projecting over apex of tergum $\mathrm{X}$; males without swollen and conical thornpads on lower posterior margin of anal segment (genus Otraleus) ....................2

2. Elytra and alae present

Otraleus christianae sp. nov.

- Elytra and alae absent ...3 
3. Abdominal terga armed with spines or tubercles posteromedially .4

- Abdominal terga smooth

Otraleus applai sp. nov.

4. Vertex elongated and slightly conical; meso- and metanotum with a definite, vertical, elongated blunt spine posteromedially

..Otraleus bellemansae sp. nov.

- Vertex not conical; meso- and metanotum at best with a short conical spine posteromedially ...

Otraleus elizabethae sp. nov.
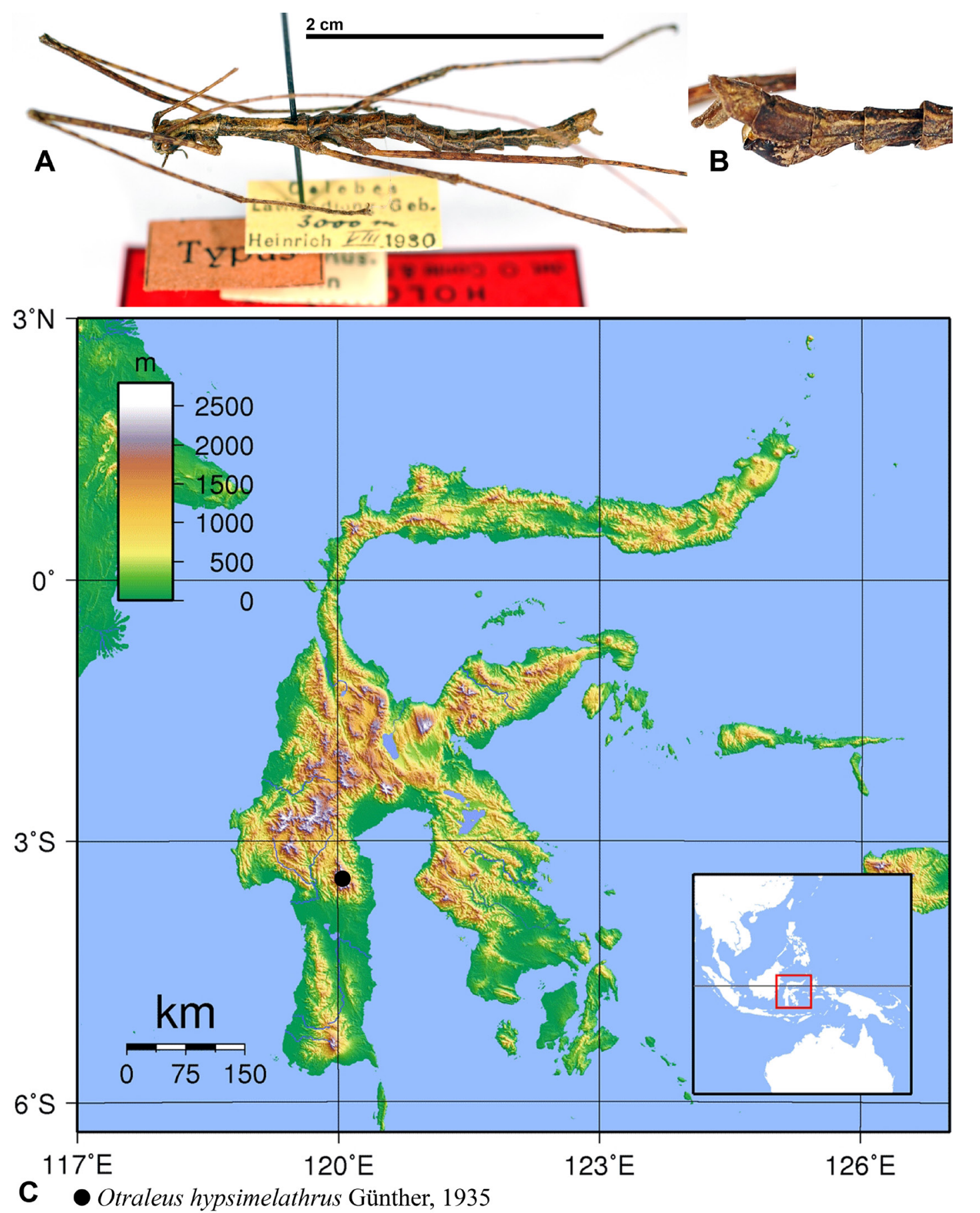

Fig. 1. Otraleus hypsimelathrus Günther, 1935, ô, holotype (ZMHB). A. Habitus, lateral view. B. Apex of abdomen, lateral view. C. Distribution map in Sulawesi. (Photographs (C) O. Conle and F. Hennemann.) 


\section{Distribution}

Currently known from Sulawesi (Indonesia), Borneo (Malaysia: Sabah) and Luzon Island (Philippines).

Otraleus applai sp. nov. urn:1sid:zoobank.org:act:3F20ECE6-CD68-4DD8-ABAD-CDC9828248E4

Figs $2-4,5 \mathrm{~A}-\mathrm{B}$

\section{Etymology}

The species epithet refers to the Applai tribe to which belong the people living in Sagada, where the type specimens were collected, in acknowledgement of their support to our research in Sagada. It is used as a noun in apposition and is indeclinable.

\section{Type material}

\section{Holotype}

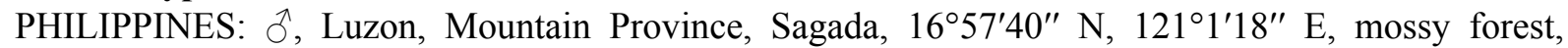
15 Apr. 2014, Mission Leopold III funds, Constant J., Bresseel J. and co. leg. (RBINS IG: 32700).

\section{Paratypes $(2 \hat{\partial} \widehat{\partial}, 7$ 우)}

PHILIPPINES: $1 \hat{0}, 2$ 우, same collection data as holotype ( 1 q in RBINS; $1 \hat{0}, 1$ in UPLB); 1 ô, 3 우, Luzon, Benguet Province, Bokod, Mt Pack/Mt Purgatory, 11 Apr. 2013, T. Heitzmann and J.P. Ortega leg. (RBINS); 1 + , Luzon Benguet Province, Mt Komkompol, 8 May 2013, T. Heitzmann and J.P. Ortega leg. (RBINS); 1 , , Luzon, Mountain Province, Bontoc-Barlig, 1500-2000 m, 17 ${ }^{\circ} 1^{\prime} 48^{\prime \prime} \mathrm{N}$, $121^{\circ} 14^{\prime} 48^{\prime \prime}$ E, 12 Apr. 2014, Mission Leopold III funds, Constant J., Bresseel J. and co. leg. (RBINS IG: 32700$)$.

\section{Description}

Male (Fig. 2)

Measurements. See Table 1.

BoDy. Colouration dark brown.

Table 1. Measurements (mm) of Otraleus applai sp. nov. HT = holotype; PT = paratype(s).

\begin{tabular}{|c|c|c|c|}
\hline & HT $\lesssim$ & PT ふえへ & PT + 우 \\
\hline Body & 41.8 & $38.4-43.4$ & $43.4-53.0$ \\
\hline Head & 2.5 & $2.2-2.7$ & $4.0-4.7$ \\
\hline Pronotum & 2.3 & $1.9-2.4$ & $2.9-3.3$ \\
\hline Mesonotum & 10.3 & $8.9-10.1$ & $9.8-12.9$ \\
\hline Metanotum & 2.7 & $2.3-2.4$ & $2.9-3.7$ \\
\hline Median segment & 2.6 & $2.2-2.3$ & $2.2-3.1$ \\
\hline Profemora & 13.9 & $13.3-14.1$ & $12.6-15.0$ \\
\hline Mesofemora & 9.1 & $9.1-9.6$ & $8.7-10.9$ \\
\hline Metafemora & 13.6 & $12.5-13.9$ & $12.1-15.0$ \\
\hline Protibiae & 13.7 & $13.5-13.8$ & $12.5-15.7$ \\
\hline Mesotibiae & 9.2 & $8.4-8.7$ & $8.5-10.4$ \\
\hline Metatibiae & 14.3 & $13.1-13.8$ & $12.8-16.1$ \\
\hline
\end{tabular}




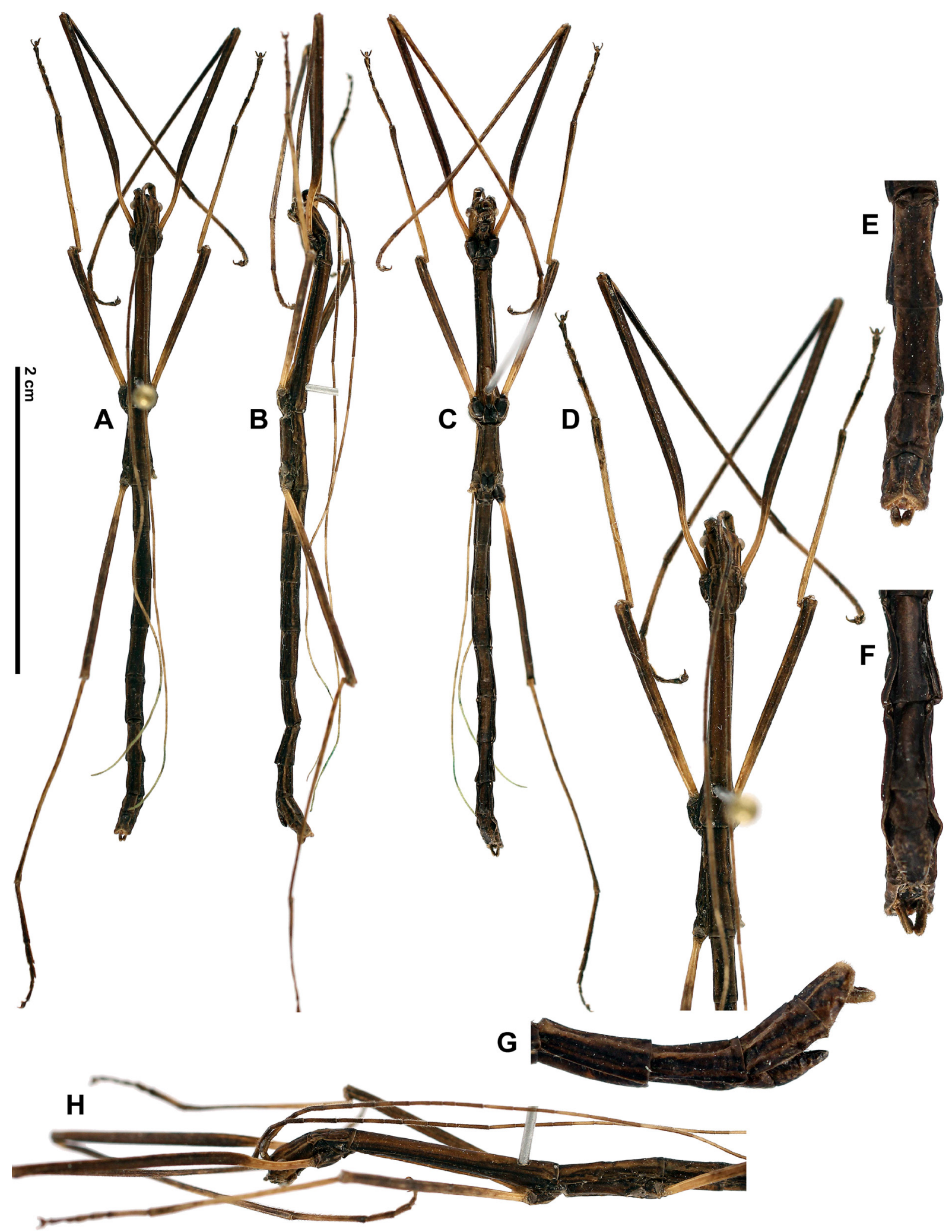

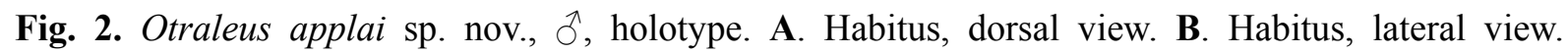
C. Habitus, ventral view. D. Anterior part of body, dorsal view. E. Apex of abdomen, dorsal view. F. Apex of abdomen, ventral view. G. Apex of abdomen, lateral view. H. Anterior part of body, lateral view. D-H: not to scale. 


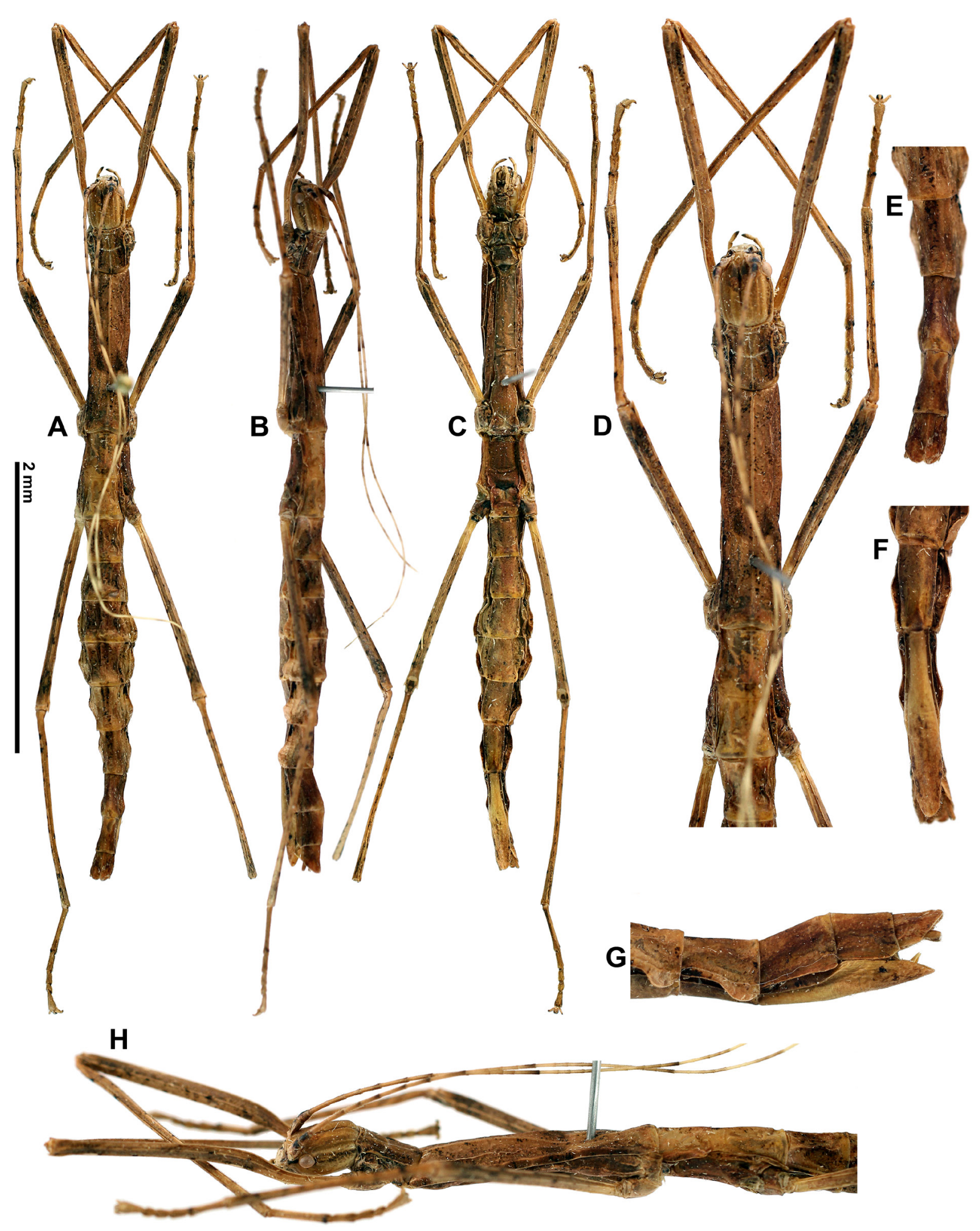

Fig. 3. Otraleus applai sp. nov., + , paratype. A. Habitus, dorsal view. B. Habitus, lateral view. C. Habitus, ventral view. D. Anterior part of body, dorsal view. E. Apex of abdomen, dorsal view. F. Apex of abdomen, ventral view. G. Apex of abdomen, lateral view. H. Anterior part of body, lateral view. D-H: not to scale. 
HEAD. Longer than wide, notched dorsally between antennae. Behind notch a raised area between eyes. Dorsally with a longitudinal median furrow. Eyes circular and strongly projecting hemispherically. Antennae with scapus flattened dorsoventrally. Pedicellus shorter than scapus and round in cross section. Antennomeres narrower than pedicellus, setose and varying in length towards apex.

Thorax. Pronotum slightly shorter than head, with anterior margin slightly concave. Behind anterior margin a V-like groove and a longitudinal groove. Centrally a second transverse, concave groove and a small impression anteriorly of transverse groove. Mesonotum elongate, scarcely granulose, with a longitudinal median line. Metanotum about the same length as pronotum.

ABDOMEN. Median segment about as long as metanotum, slightly widening towards the posterior. Abdominal terga smooth, terga III-VI about the same length. Following segments gradually decreasing in length. Tergum IX slightly compressed laterally. Tergum X with longitudinal carina and posterior edge notched. Posterolateral angles triangular but blunt. Ventral surface of posterior margin of tergum $\mathrm{X}$ armed with few, small black spines. Vomer well developed, visible as an elongated, flattened spine. Poculum triangular in ventral view, fairly flattened. Poculum narrowing towards the posterior, apex rounded, reaching apex of tergum IX. Cerci cylindrical in cross section, apices rounded, projecting over apex of abdomen. Abdominal sterna smooth.

LEGS. Long in comparison to body, profemora compressed and curved basally. Femora and tibiae compressed laterally, with all carinae developed. Basitarsi longer than the following tarsomeres combined. Tarsomeres gradually decreasing in length and with dorsal carina well developed, resulting in a posteromedian spine projecting over next tarsomere. Claws small.

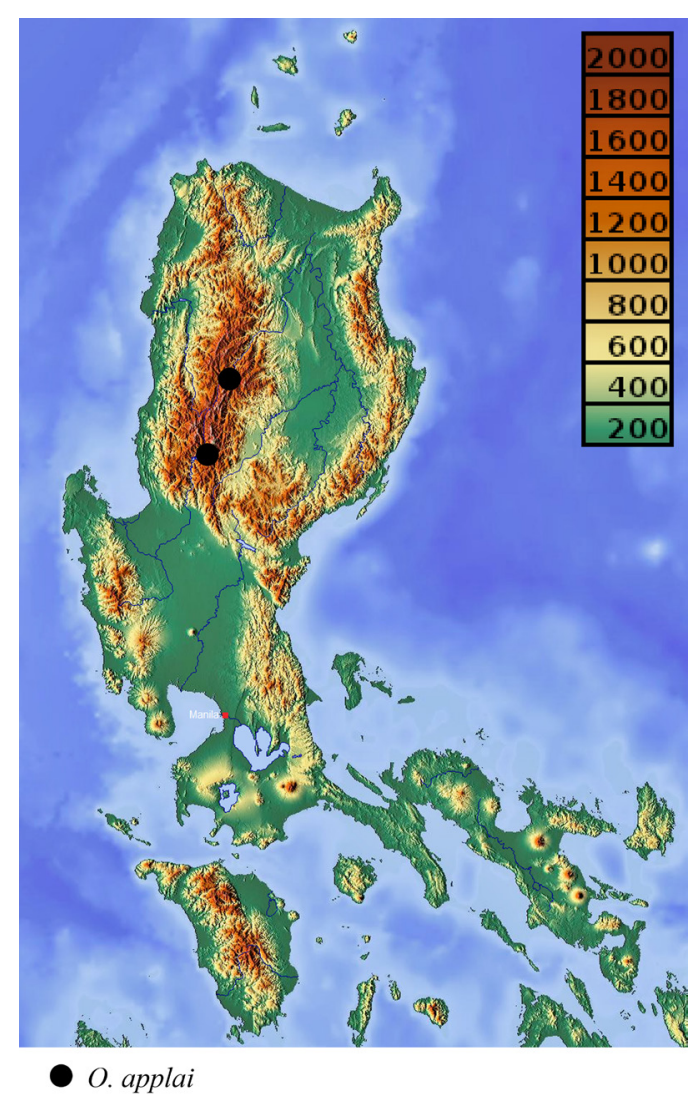

Fig. 4. Otraleus applai sp. nov. Distribution map in Luzon. 
Female (Fig. 3)

Measurements. See Table 1.

BoDy. Mottled brown and green.

HEAD. Longer than wide, notched dorsally between antennae. Behind notch a raised area between eyes. Dorsally with a fine longitudinal median furrow. Eyes circular and strongly projecting hemispherically. Antennae with scapus flattened dorsoventrally. Pedicellus shorter than scapus and round in cross section. Antennomeres narrower than pedicellus. Antennomeres varying in length towards apex.

Thorax. Pronotum shorter than head, granulose, with anterior edge slightly concave. Behind anterior edge a transverse groove and a longitudinal groove. Pronotum slightly constricted in anterior half. Centrally a second transverse, concave groove and a small, oval impression anteriorly of transverse groove. Mesonotum elongate, scarcely granulose, with a longitudinal median line. Metanotum about same length as pronotum. Medially with a tubercle subapically.

ABdomen. Median segment slightly shorter than metanotum. Terga III-VIII with postero-laterally well developed lobes in posterior half. Abdominal terga IV-V widest. Terga VIII-X laterally compressed. Tergum X notched posteriorly, posterolateral angles rounded. Cerci small, cylindrical in cross section, apices rounded, reaching apex of abdomen. Abdominal sterna smooth. Subgenital plate compressed laterally, rounded posteriorly, not reaching apex of abdomen.

LEGS. Long, profemora compressed and curved basally. Femora and tibiae slightly compressed laterally, with all carinae developed. Meso- and metafemora slightly widening towards the posterior. Tarsomeres gradually decreasing in length and with dorsal carina well developed, resulting in a posteromedian spine projecting over next tarsomere. Claws small.

\section{Distribution}

The species has so far only been recorded from Luzon, Mountain Province and Benguet Province (see map Fig. 4).

\section{Otraleus bellemansae sp. nov. urn:1sid:zoobank.org:act:1C1D03CE-F610-4F37-9EFF-7D5C776BF912}

Figs $5 \mathrm{C}-\mathrm{H}, 6-7,13$

\section{Etymology}

This species epithet is dedicated to Nathalie Bellemans (Zemst, Belgium) for her support and help with the first author's research for several years.

\section{Type material}

\section{Holotype}

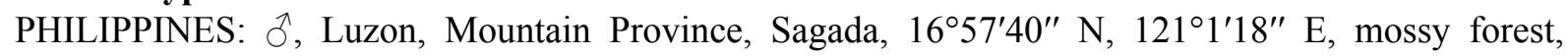
15 Apr. 2014, Mission Leopold III funds, Constant J., Bresseel J. and co. leg. (RBINS IG: 32700).

\section{Paratype}

PHILIPPINES: 1 , same collection data as holotype (RBINS).

\section{Description}

The colouration is described from photographs of live specimens. 
Male (Fig. 6)

Measurements. See Table 2.

BoDy. Brown to green with black patches scattered over body and legs.

HEAD. Longer than wide, notched dorsally between antennae. Vertex with a prominent blunt elevation. Elevation split by a shallow longitudinal depression. Eyes circular and strongly projecting hemispherically. Antennae slightly setose, widely projecting over apex of abdomen. Scapus slightly flattened dorsoventrally, subcylindrical in cross section. Pedicellus shorter than scapus and round in cross section. Following segments narrower than pedicellus and varying in length towards apex.

ThORAX. Pronotum with anterior margin slightly concave, followed by a transverse groove. A longitudinal median groove starting at anterior edge, not reaching posterior tubercle. Centrally a definite transverse depression. Posteromedially with a small, blunt tubercle. Mesonotum scarcely granulose, slightly widening towards the posterior. Posteromedially with a definite blunt spine, posterolateral edges humped. Metanotum about as long as pronotum. Posteromedially with a definite blunt spine. Posterolateral edges humped.

ABDOMEN. Median segment slightly widening towards posterior with a blunt spine posteromedially. Terga II-VIII with short, tapered lobes posterolaterally and with a blunt elevation posteromedially. Tergum IX slightly laterally compressed. Tergum $\mathrm{X}$ with posterior edge incised, posterolateral angles rounded, armed ventrally with small black spines. Vomer well developed, visible as an elongated, flattened spine. Apex of vomer visible dorsally between lateral edges of tergum X. Poculum triangular in ventral view, fairly flattened. Poculum narrowing towards posterior, apex rounded, reaching apex of tegum IX. Cerci cylindrical in cross section, apices incurved and blunt, projecting over apex of abdomen. Abdominal sterna smooth.

LeGs. Long, profemora compressed and curved basally. Femora and tibiae compressed laterally, with all carinae developed. Basitarsi longer than following tarsomeres combined. Claws small.

Female (Fig. 7)

MeAsurements. See Table 2.

Table 2. Measurements (mm) of Otraleus bellemansae sp. nov. HT = holotype; PT = paratype.

\begin{tabular}{lcc}
\hline & HT ${ }^{\hat{\gamma}}$ & PT + \\
\hline Body & 41.9 & 45.2 \\
Head & 3.6 & 4.9 \\
Pronotum & 2.7 & 3.7 \\
Mesonotum & 9.6 & 10.1 \\
Metanotum & 3.0 & 3.3 \\
Median segment & 2.3 & 2.9 \\
Profemora & 15.2 & 13.3 \\
Mesofemora & 11.4 & 10.0 \\
Metafemora & 15.3 & 15.2 \\
Protibiae & 15.4 & 14.5 \\
Mesotibiae & 11.3 & 10.9 \\
Metatibiae & 15.1 & 16.5 \\
\hline
\end{tabular}




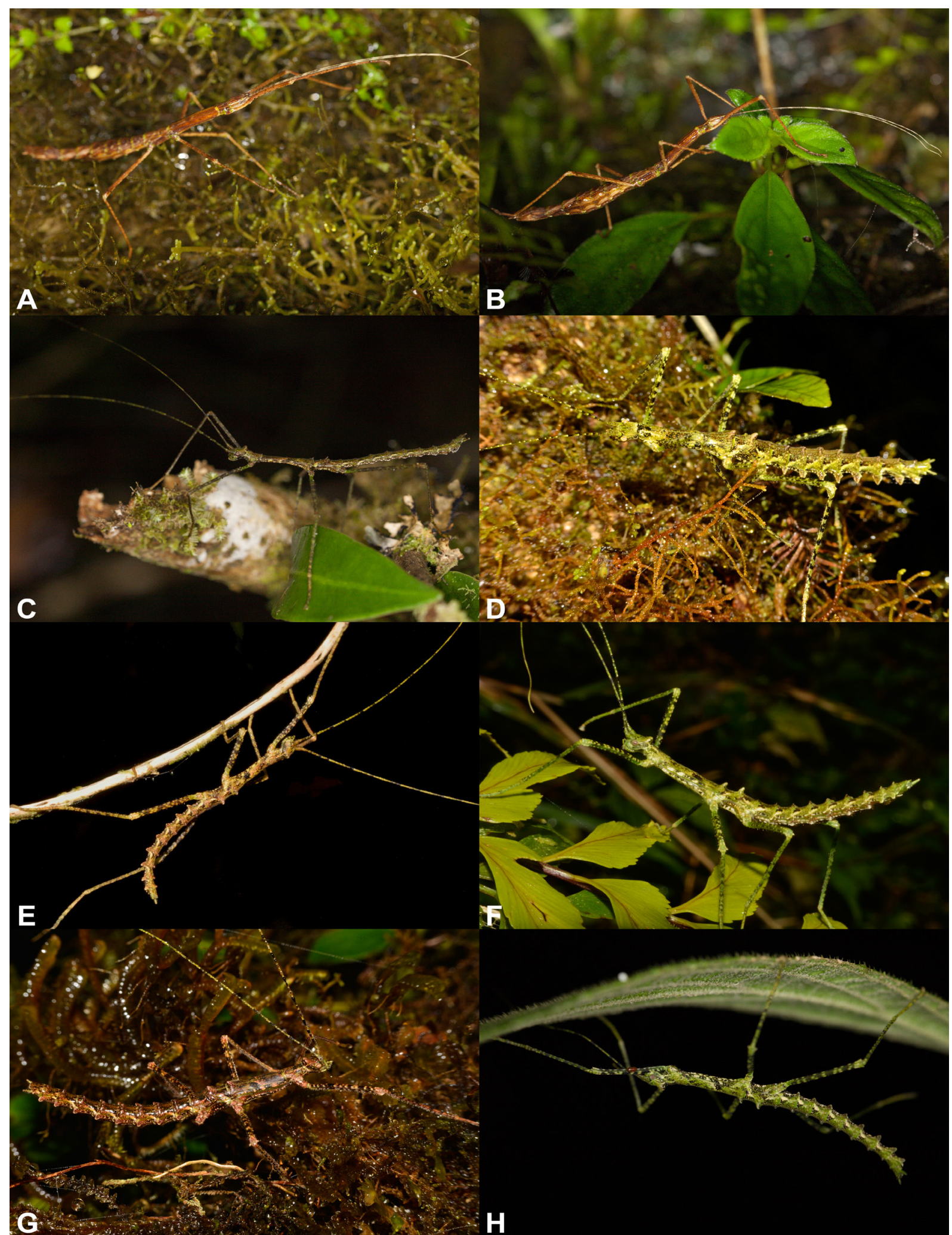

Fig. 5. Otraleus spp., photographs in natura. — A-B. O. applai sp. nov., 9 , 15 Apr. 2014. -

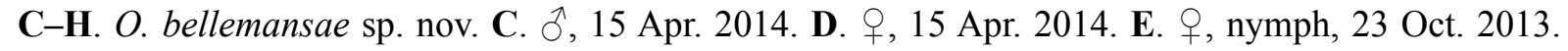

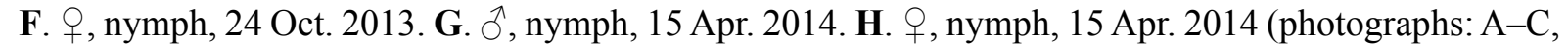
H C A. Lefèvre; D-G (C) A. Kang). 


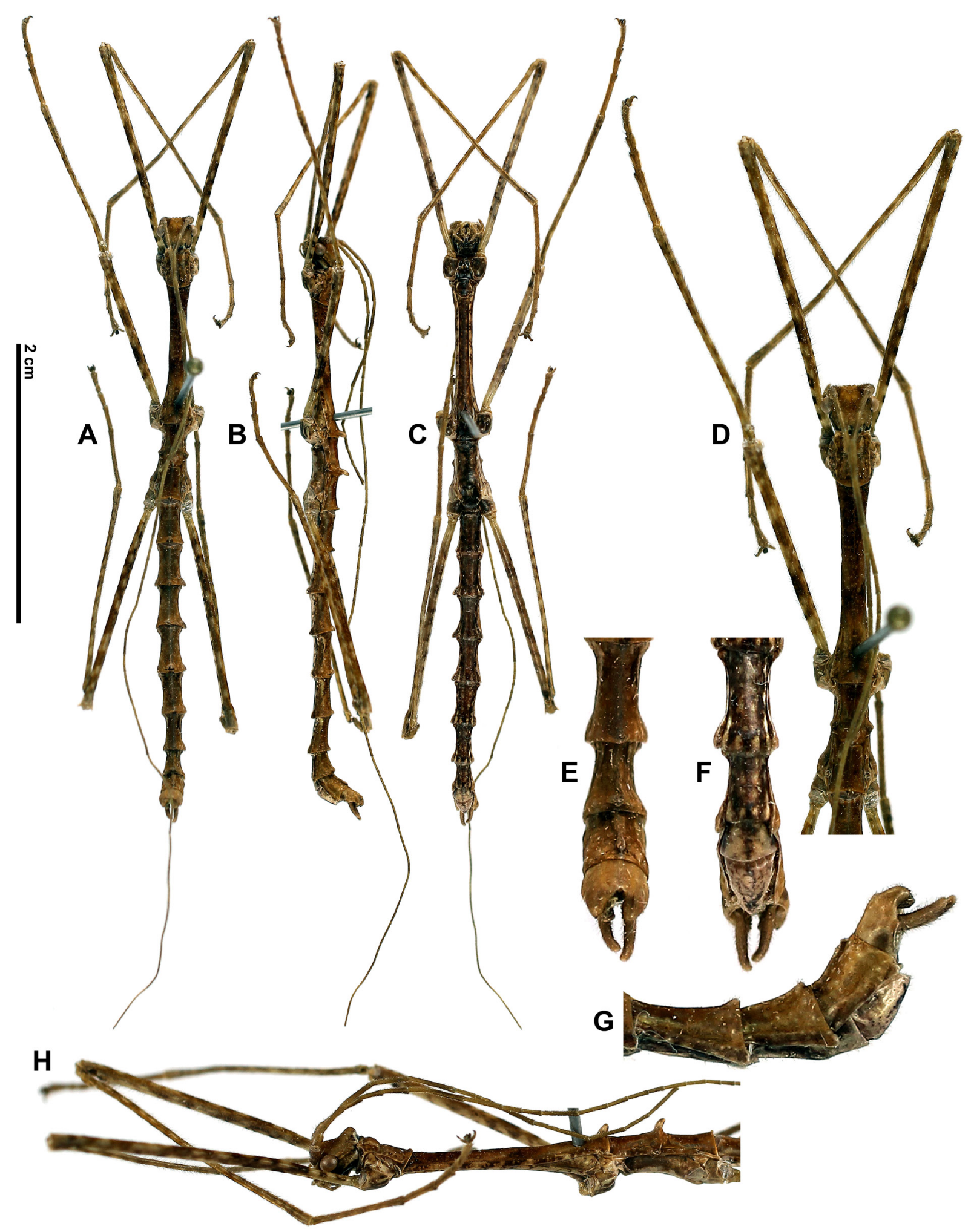

Fig. 6. Otraleus bellemansae sp. nov., $\widehat{\partial}$, holotype. A. Habitus, dorsal view. B. Habitus, lateral view. C. Habitus, ventral view. D. Anterior part of body, dorsal view. E. Apex of abdomen, dorsal view. F. Apex of abdomen, ventral view. G. Apex of abdomen, lateral view. H. Anterior part of body, lateral view. D-H: not to scale. 


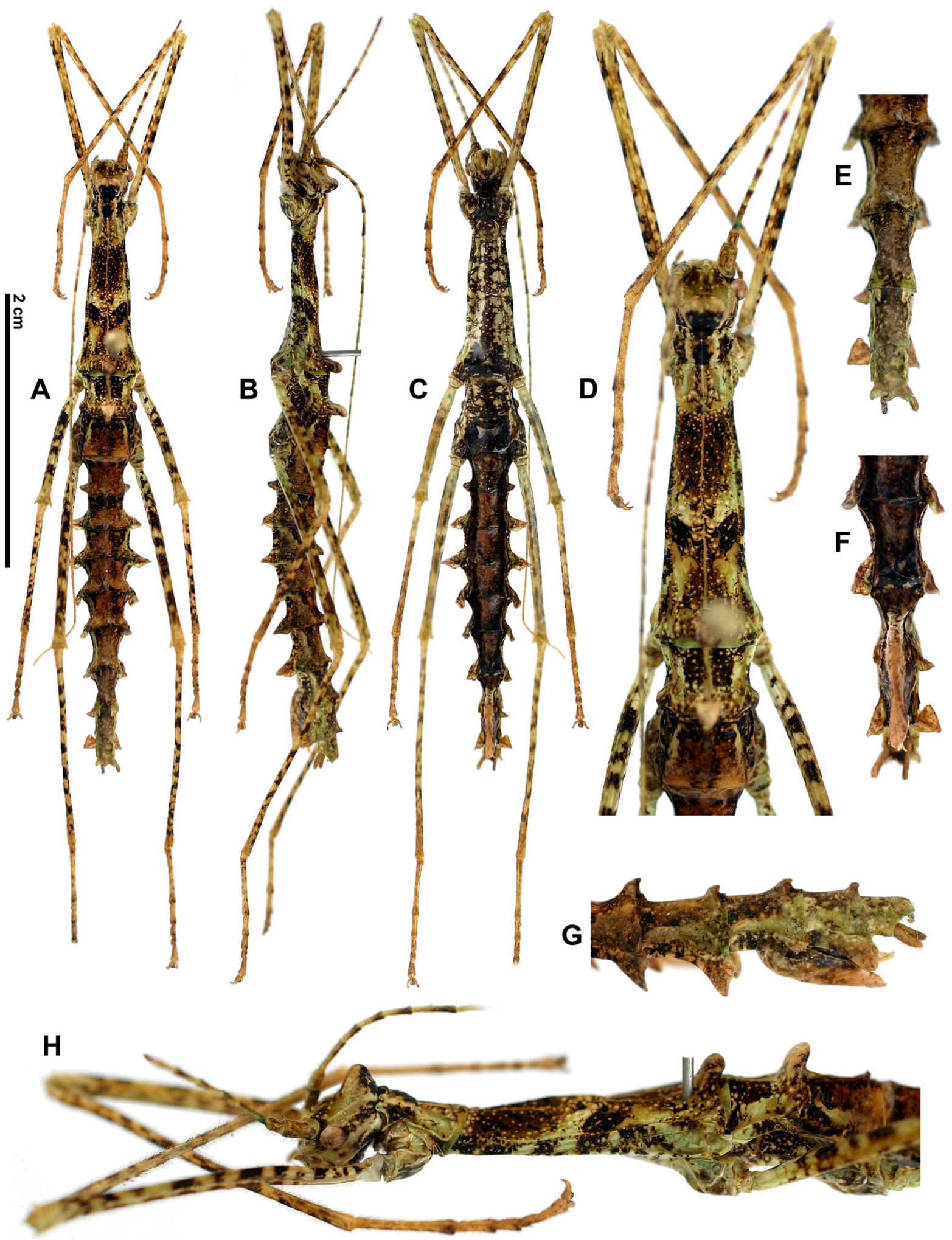

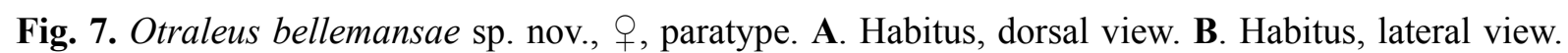
C. Habitus, ventral view. D. Anterior part of body, dorsal view. E. Apex of abdomen, dorsal view. F. Apex of abdomen, ventral view. G. Apex of abdomen, lateral view. H. Anterior part of body, lateral view. D-H: not to scale. 
BoDy. Brown to green with black patches scattered over body and legs.

HEAD. Longer than wide, notched dorsally between antennae. Vertex with a prominent blunt elevation. Elevation split by a shallow longitudinal depression. Eyes circular and strongly projecting hemispherically. Antennae slightly setose, almost reaching apex of abdomen but broken. Scapus slightly flattened dorsoventrally, subcylindrical in cross section. Pedicellus shorter than scapus and round in cross section. Following segments narrower than pedicellus and varying in length towards apex.

Thorax. Pronotum with anterior edge incurved and raised, followed by a transverse groove. A longitudinal median groove starting behind anterior edge, not reaching posterior tubercle. Slightly constricted submedially, with a second transverse impression. Posteromedially with a small, blunt tubercle. Mesonotum scarcely granulose, slightly widening towards posterior. Posteromedially with a definite blunt spine. Lateral margins projecting posterolaterally. Metanotum shorter than pronotum. Posteromedially with a definite blunt, spinose tubercle. Lateral margins projecting posterolaterally.

ABDOMEN. Median segment widening towards posterior with a blunt spine posteromedially. Terga IIVIII with posterolaterally well developed lobes and posteromedially with a curved, slightly laterally compressed spine. Abdominal terga IV-V widest. Terga VIII-X laterally compressed. Tergum X with posterior edge incurved, posterolateral angles rounded mediolaterally with a small lobe. Epiproct small, visible as small, posteriorly rounded plate; not projecting over posterolateral angles of tergum X. Cerci small, cylindrical in cross section, apex rounded, slightly projecting over apex of abdomen. Abdominal sterna smooth. Subgenital plate compressed laterally, rounded posteriorly, not reaching apex of abdomen.

LEgs. Long when compared to body. Profemora compressed and curved basally. Femora and tibiae compressed laterally, with all carinae developed. Meso- and metafemora slightly widening towards the posterior. Basitarsi longer than following tarsomeres combined. Tarsomeres gradually decreasing in length and with dorsal carina well developed, resulting in a posteromedian ridge. Claws small.

\section{Distribution}

The species is recorded from Luzon, Mountain Province (see map Fig. 13).

\section{Otraleus christianae sp. nov. urn:1sid:zoobank.org:act:C5DC9E74-E012-4DCA-8442-5C03635AEBEC}

Figs $8-9,10 \mathrm{~A}-\mathrm{F}, 13$

\section{Etymology}

The species epithet is given in honour of Mrs Christiane Schneider, the mother of Mr Thierry Heitzmann, one of the collectors of the type specimens.

\section{Type material}

\section{Holotype}

PHILIPPINES: $\widehat{\jmath}$, North Luzon, Mt Polis, Nov. 2013, T. Heitzmann leg. (RBINS).

Paratypes $(1 \stackrel{+}{1}, 1$ $)$

PHILIPPINES: 1 + , same collection data as holotype (RBINS); $1 \hat{\jmath}$, same data (UPLB).

\section{Description}

The colouration is described from photographs of live specimens. 
Male (Fig. 8)

Measurements. See Table 3.

BoDy. Brown to green with black patches scattered over body and legs.

HEAD. Longer than wide, notched dorsally between antennae, followed by a longitudinal groove reaching vertex. Between eyes, a raised circular area surrounded by a ring of granules. Vertex split, slightly elevated and rounded. Eyes circular and strongly projecting hemispherically. Antennae slightly setose, projecting over apex of abdomen but broken. Scapus slightly flattened dorsoventrally, subcylindrical in cross section. Pedicellus shorter than scapus and round in cross section. Antennomeres narrower than pedicellus and varying in length towards apex.

Thorax. Pronotum with anterior edge incurved and raised, followed by a transverse groove. A longitudinal median groove starting behind anterior edge, reaching posterior margin. Pronotum slightly constricted, with a second transverse impression before centre. Mesonotum smooth, slightly widening towards posterior. Centrally with two definite tubercles. Posteromedially with a small hump.

Wings. Tegmina short, rounded, not reaching margin of median segment and with a small hump anterolaterally. Alae short, anal area transparent, projecting over apex of tergum III.

ABDOMEN. Median segment widening towards posterior. Terga II-VII with posterolaterally small, but well developed lobes. Terga V-IX with a posteromedian hump. Tergum X with posterior edge incurved, posterolateral angles rounded, swollen and armed with small black spines ventrally. Cerci small, round in cross section; apices slightly incurved and rounded, projecting over apex of abdomen. Vomer well developed, visible as an elongated, black, flattened spine with paler apex. Poculum slightly flattened, triangular in ventral view, narrowing towards posterior; apex acute, reaching apex of tergum IX.

LEGS. Long when compared to body, profemora compressed and curved basally. Femora and tibiae compressed laterally, with all carinae developed. Basitarsi longer than following tarsomeres combined. Tarsomeres gradually decreasing in length. Claws small.

Female (Fig. 9)

MeAsurements. See Table 3.

Table 3. Measurements ( $\mathrm{mm})$ of Otraleus christianae sp. nov. HT = holotype; PT = paratype.

\begin{tabular}{lccc}
\hline & HT $\boldsymbol{O}^{\wedge}$ & PT $\AA^{\wedge}$ & PT + \\
\hline Body & 48.8 & 42.9 & 51.7 \\
Head & 3.2 & 2.6 & 4.9 \\
Pronotum & 2.7 & 2.3 & 3.4 \\
Mesonotum & 10.8 & 9.6 & 12.1 \\
Profemora & 14.6 & 14.7 & 15.2 \\
Mesofemora & 12.0 & 10.9 & 11.9 \\
Metafemora & 16.8 & 15.8 & 17.1 \\
Protibiae & 15.0 & 14.2 & 16.2 \\
Mesotibiae & 11.3 & 11.2 & 12.3 \\
Metatibiae & 17.7 & 16.7 & 18.3 \\
Tegmina & 2.5 & 2.1 & 3.0 \\
Alae & 13.9 & 13.6 & 15.0 \\
\hline
\end{tabular}




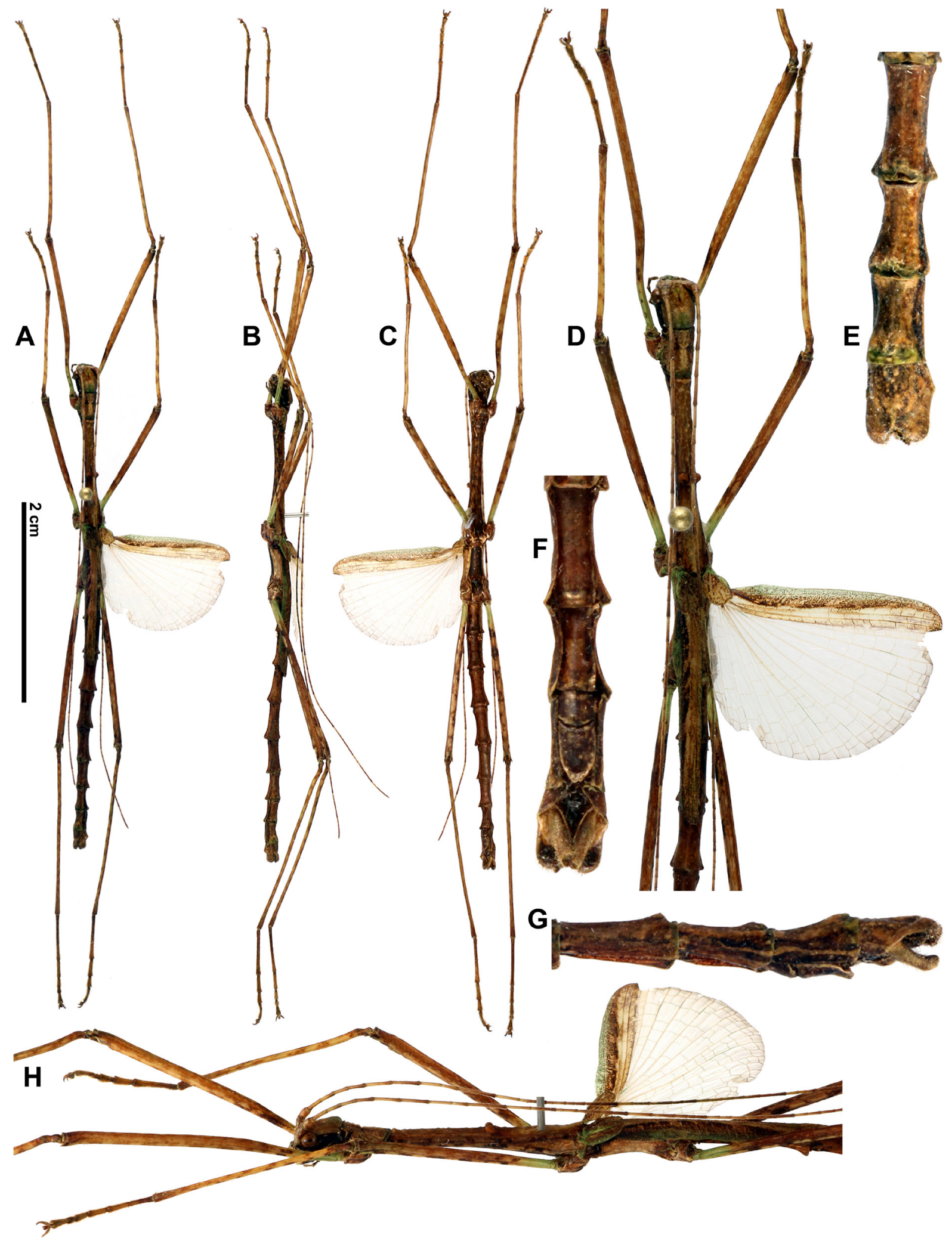

Fig. 8. Otraleus christianae sp. nov., $\hat{\jmath}$, holotype. A. Habitus, dorsal view. B. Habitus, lateral view. C. Habitus, ventral view. D. Anterior part of body, dorsal view. E. Apex of abdomen, dorsal view. F. Apex of abdomen, ventral view. G. Apex of abdomen, lateral view. H. Anterior part of body, lateral view. D-H: not to scale. 


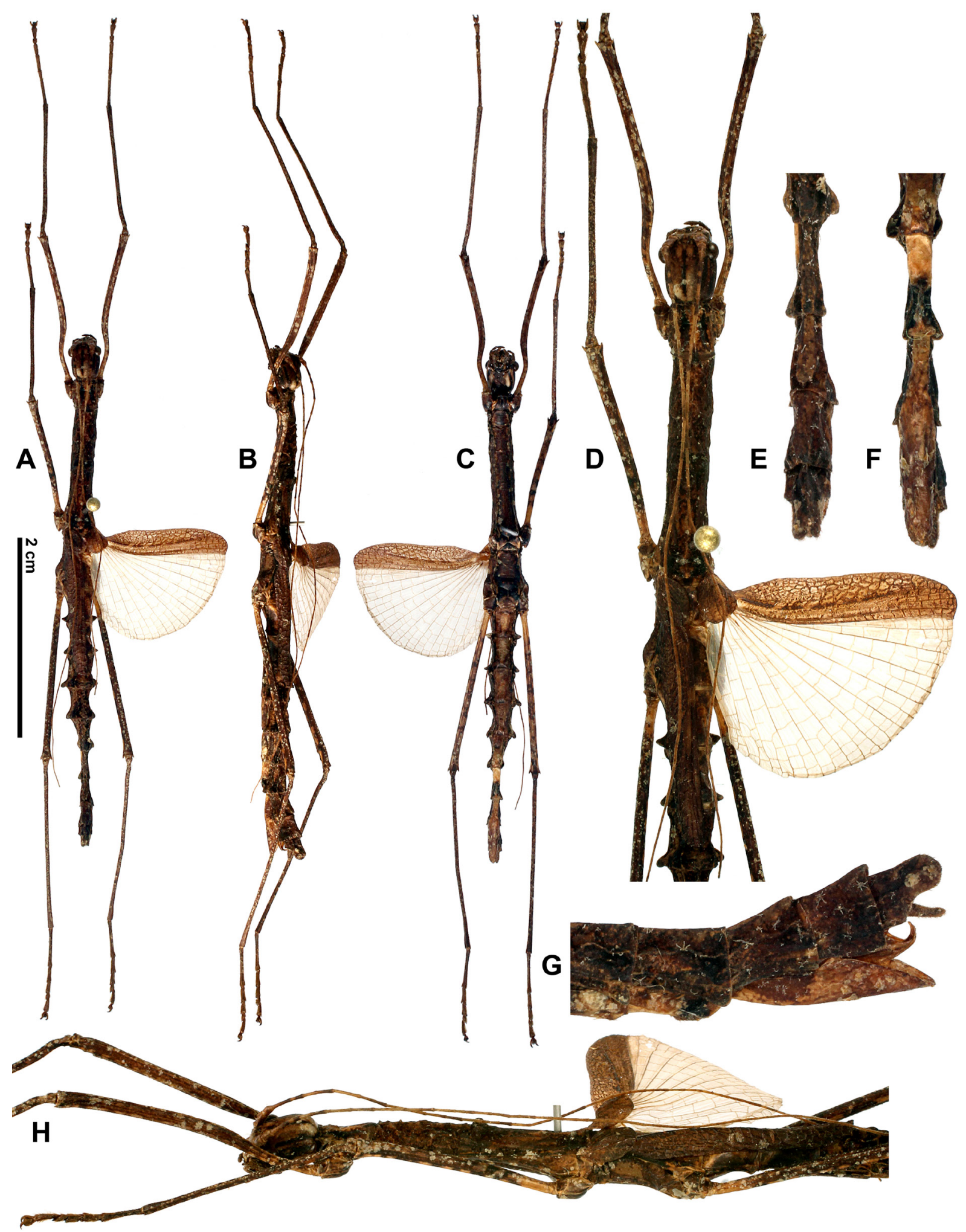

Fig. 9. Otraleus christianae sp. nov., ${ }$, paratype. A. Habitus, dorsal view. B. Habitus, lateral view. C. Habitus, ventral view. D. Anterior part of body, dorsal view. E. Apex of abdomen, dorsal view. F. Apex of abdomen, ventral view. G. Apex of abdomen, lateral view. H. Anterior part of body, lateral view. D-H: not to scale. 


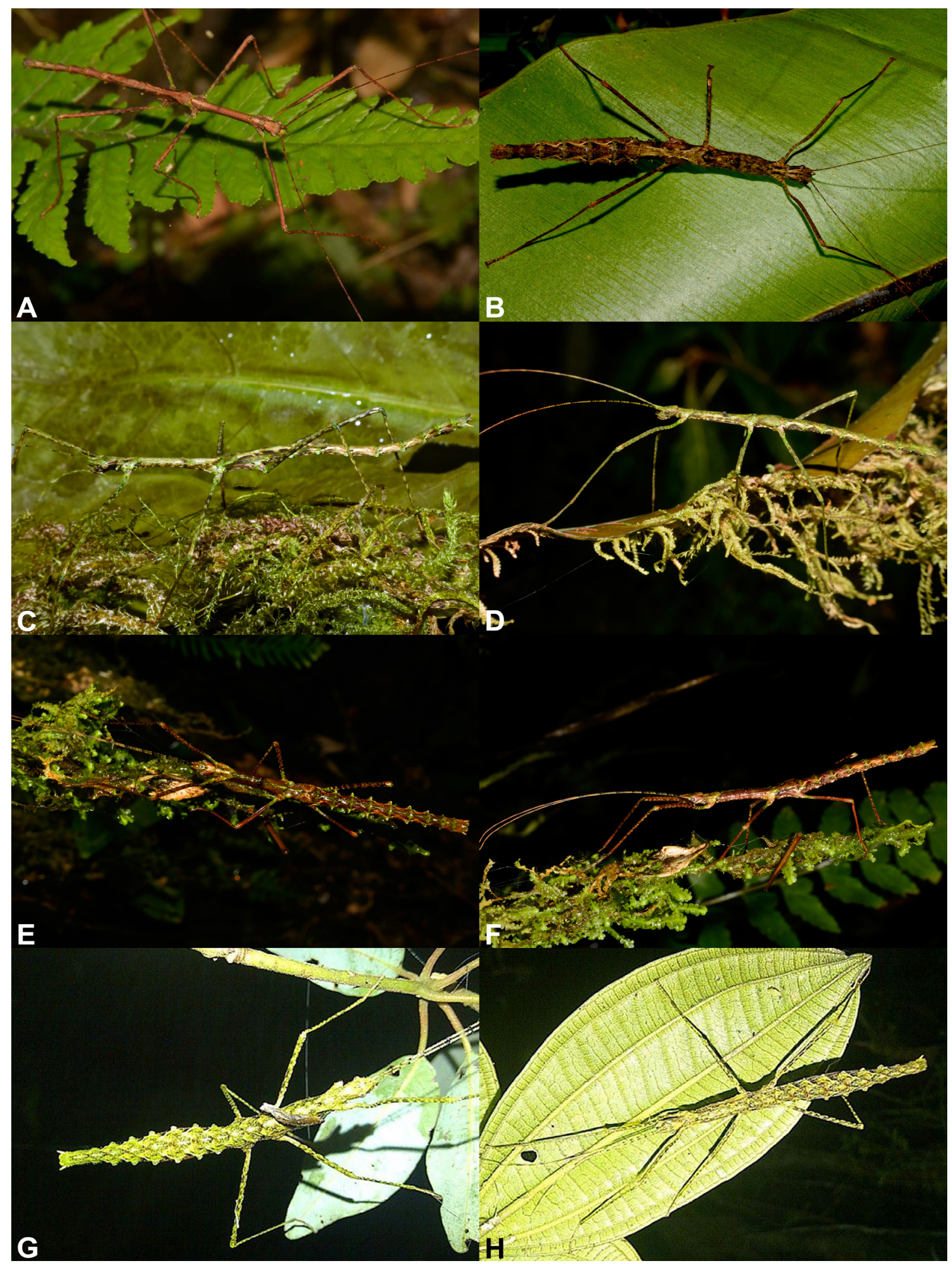

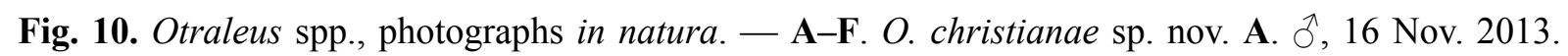

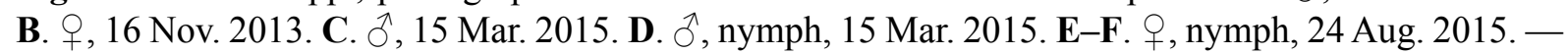
G-H. O. elizabethae sp. nov.,, , 11 Apr. 2013 (photographs: A-F ( $)$ A. Kang; G-H ( $)$ T. Heitzmann). 
BoDy. Brown to green with black patches scattered over body and legs.

HEAD. Longer than wide, notched dorsally between antennae, followed by a longitudinal groove reaching vertex. Between eyes a raised circular area surrounded by granules. Vertex slightly elevated and rounded. Eyes circular and strongly projecting hemispherically. Antennae slightly setose, almost reaching apex of abdomen but broken. Scapus slightly flattened dorsoventrally, subcylindrical in cross section. Pedicellus shorter than scapus and round in cross section. Antennomeres narrower than pedicellus and varying in length towards apex.

THORAX. Pronotum with anterior edge incurved and raised, followed by a transverse groove. A longitudinal median groove starting behind anterior edge, reaching posterior margin. Pronotum slightly constricted subcentrally and with second transverse impression. Mesonotum scarcely granulose, slightly widening towards posterior. Centrally with two definite tubercles. Posteromedially with a small hump.

Wings. Tegmina short, rounded, not reaching posterior margin of median segment and with a small hump antero-laterally, veins thickened. Alae short, anal area transparent, not reaching apex of tergum IV.

ABDOMEN. Median segment widening towards posterior. Terga II-VII with posterolaterally well developed lobes. Terga VIII-X laterally compressed. Tergum X with posterior edge incurved, postero-lateral angles rounded. Cerci small, round in cross section; apices slightly flattened and rounded, reaching apex of abdomen. Abdominal sterna smooth, sternum VII with a small ridge posteromedially. Subgenital plate compressed laterally, narrowing posteriorly, not reaching apex of abdomen.

LEGS. Long when compared to body, profemora compressed and curved basally. Femora and tibiae compressed laterally, with all carinae developed. Basitarsi longer than following tarsomeres combined. Tarsomeres gradually decreasing in length. Claws small.

\section{Distribution}

The species is recorded from Luzon, Mountain Province (see map Fig. 13).

Otraleus elizabethae sp. nov. urn:1sid:zoobank.org:act:AB74A621-EEA9-46C2-ACDB-BD102ECC819D

Figs 10G-H, 11-13, 14A

\section{Etymology}

The species epithet is named after Mrs Elizabeth Lumawig, the wife of Mr Thierry Heitzmann, one of the collectors of the type series.

\section{Type material}

Holotype

PHILIPPINES: §̋, Luzon, Benguet Province, Bokod, Mt Komkompol, 8 May 2015, T. Heitzmann and J.P. Ortega leg. (RBINS). 
Table 4. Measurements (mm) of Otraleus elizabethae sp. nov. HT = holotype; PT = paratype(s).

\begin{tabular}{lccc}
\hline & HT ${ }^{\wedge}$ & PT & PT \\
\hline Body & 38.3 & $33.9-36.0$ & $44.5-46.6$ \\
Head & 2.7 & $2.0-2.5$ & $3.5-4.1$ \\
Pronotum & 2.4 & $2.0-2.3$ & $2.9-3.1$ \\
Mesonotum & 7.6 & $7.5-7.7$ & $9.9-10.0$ \\
Metanotum & 2.7 & $2.2-2.5$ & $2.8-3.1$ \\
Median segment & 2.2 & $2.0-2.1$ & $2.6-2.7$ \\
Profemora & 13.8 & $12.5-12.7$ & $12.7-14.5$ \\
Mesofemora & 10.3 & $9.4-10.0$ & $11.8-11.9$ \\
Metafemora & 14.9 & $13.9-14.6$ & $16.7-16.8$ \\
Protibiae & 15.2 & $13.7-14.0$ & $13.9-14.9$ \\
Mesotibiae & 11.0 & $10.0-10.2$ & $10.5-11.8$ \\
Metatibiae & 17.3 & $15.2-16.7$ & $16.6-17.7$ \\
\hline
\end{tabular}

Paratypes $(3 \hat{\partial} \widehat{\partial}, 2$ 우)

PHILIPPINES: $2 \hat{\jmath} \hat{\partial}, 1$ ㅇ, Luzon, Benguet Province, Bokod, Mt Pack/Mt Purgatory, 11 Apr. 2013, T. Heitzmann and J.P. Ortega leg. (RBINS); 1 , same data (UPLB); 1 , same collection data as holotype (UPLB).

\section{Description}

The colouration is described from photographs of live specimens.

Male (Figs 11, 14A)

MEasurements. See Table 4.

BoDy. Brown to green with black patches scattered over body and legs.

HEAD. Slightly longer than wide, notched dorsally between antennae. Notch followed by a median longitudinal impression. Between eyes a raised more or less circular area, surrounded by a group of granules. Elevation split by longitudinal line. Eyes circular and strongly projecting hemispherically. Antennae slightly setose, projecting over apex of abdomen. Scapus slightly flattened dorsoventrally. Pedicellus shorter than scapus and round in cross section. Antennomeres narrower than pedicellus and varying in length towards apex.

Thorax. Pronotum granulose, about as long as head, anterior edge raised, with two granules centrally. Posteriorly of raised rim, a transverse groove and a longitudinal median groove not reaching posterior tubercle. Just before centre, a second transverse impression and a circular impression anteriorly of transverse impression. Posteromedially with a small, blunt tubercle. Mesonotum elongated and granulose, with a definite blunt spine posteromedially. Posterolateral edges rounded. Metanotum granulose, about same length as pronotum. Medially with a definite blunt spine subapically.

AbDomen. Median segment granulose, about the same length as metanotum, with a blunt spine posteromedially. Terga II-VIII with posterolaterally well developed lobes and with a blunt spine posteromedially; slightly projecting over next segment. Tergum IX slightly laterally compressed and tectiform, with a hump posteromedially. Tergum $\mathrm{X}$ with an indefinite longitudinal ridge and with 


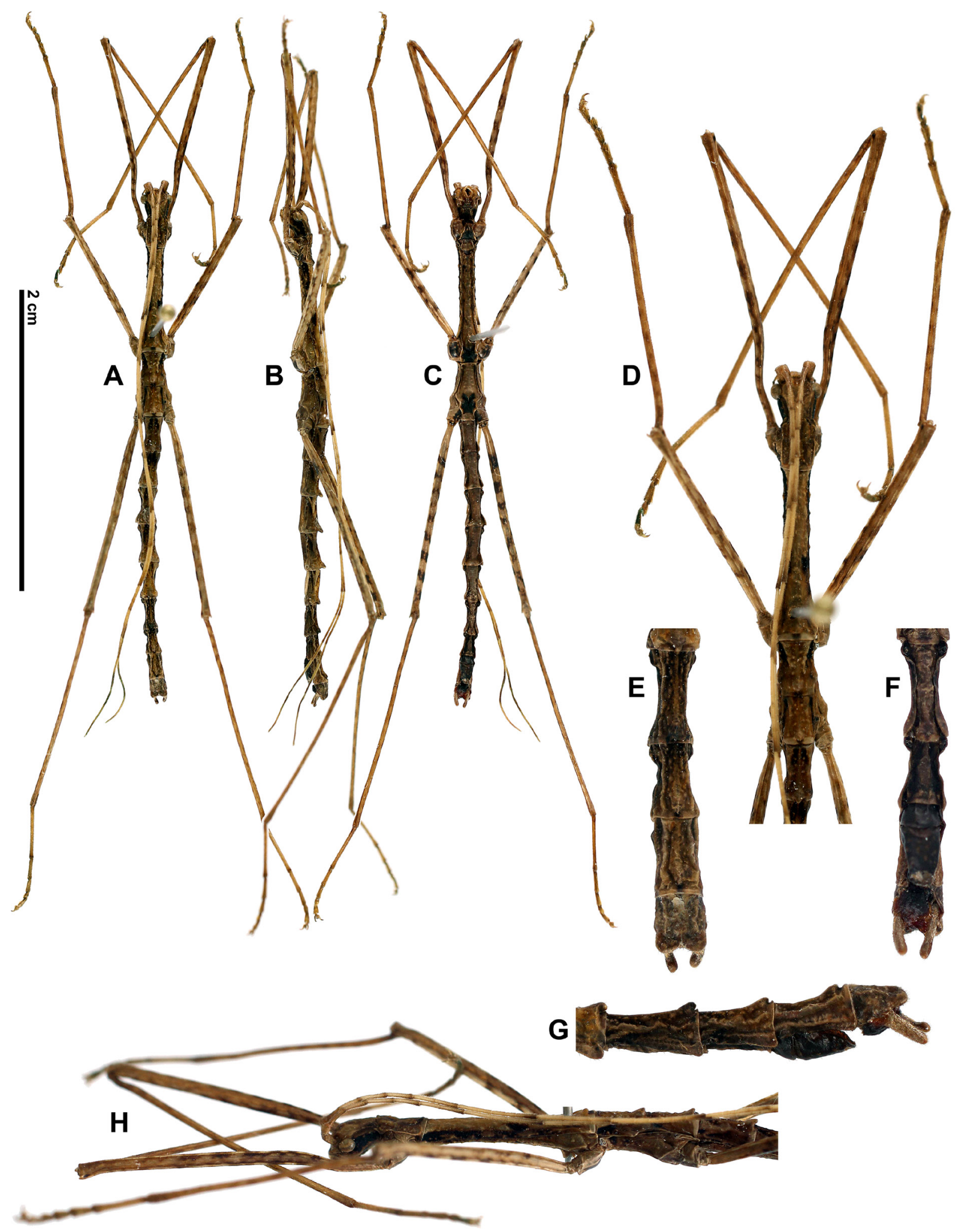

Fig. 11. Otraleus elizabethae sp. nov., $\widehat{\partial}$, holotype. A. Habitus, dorsal view. B. Habitus, lateral view. C. Habitus, ventral view. D. Anterior part of body, dorsal view. E. Apex of abdomen, dorsal view. F. Apex of abdomen, ventral view. G. Apex of abdomen, lateral view. H. Anterior part of body, lateral view. D-H: not to scale. 


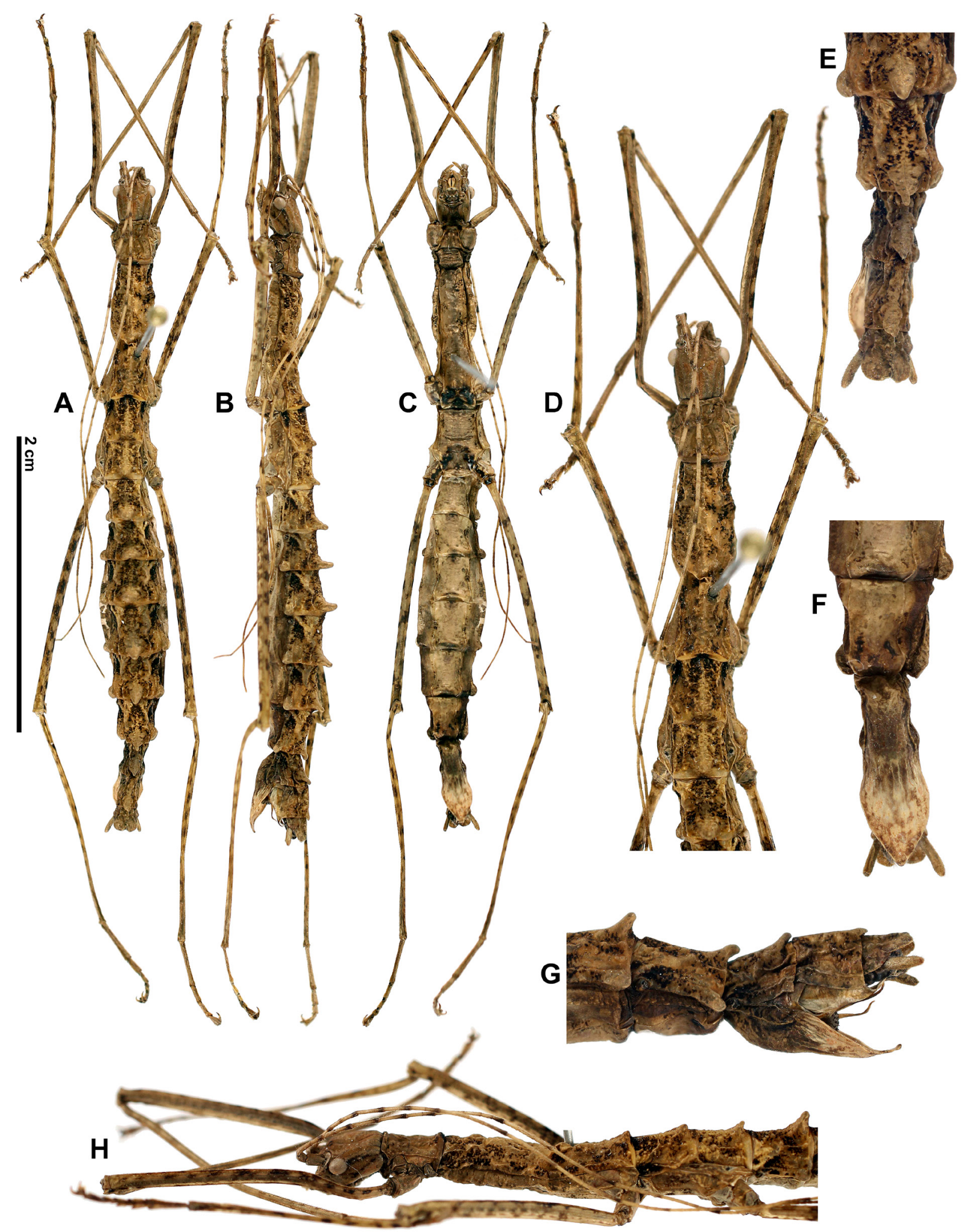

Fig. 12. Otraleus elizabethae sp. nov., + , paratype. A. Habitus, dorsal view. B. Habitus, lateral view. C. Habitus, ventral view. D. Anterior part of body, dorsal view. E. Apex of abdomen, dorsal view. F. Apex of abdomen, ventral view. G. Apex of abdomen, lateral view. H. Anterior part of body, lateral view. D-H: not to scale. 
posterior edge incurved, posterolateral angles rounded. Cerci small, round in cross section; apex rounded, projecting over apex of abdomen. Abdominal sterna smooth. Vomer well developed, visible as an elongated, black, flattened spine with paler apex. Poculum slightly flattened, narrowing towards posterior; apex rounded, reaching apex of tergum IX.

LEGs. Long, profemora compressed and curved basally. Femora and tibiae compressed laterally, with all carinae developed. Basitarsi longer than following tarsomeres combined. Tarsomeres gradually decreasing in length. Claws small.

Female (Fig. 12)

Measurements. See Table 4.

BoDy. Brown to green with black patches scattered over body and legs.

HEAD. Longer than wide, notched dorsally between antennae. Behind notch, two small, black circular dots. Dorsally with a fine longitudinal median line. Eyes circular and strongly projecting hemispherically. Antennae broken, scapus slightly flattened dorsoventrally. Pedicellus shorter than scapus and round in cross section. Antennomeres narrower than pedicellus, slightly swollen and setose apically, varying in length towards apex.

Thorax. Pronotum granulose, shorter than head, with anterior edge slightly concave and raised, with several granules. Posteriorly of raised rim, a transverse groove and a longitudinal groove not reaching posterior tubercle. Pronotum slightly constricted just before centre and with a second transverse impression and a circular impression anteriorly of transverse impression. Posteromedially with a small, blunt tubercle. Mesonotum elongated and granulose, with a definite, blunt spine posteromedially. Metanotum about same length as pronotum. Medially with a definite blunt, spinose tubercle subapically. Metanotum laterally rounded, with widest part centrally.

ABdomen. Median segment about same length as metanotum, with a blunt spine posteromedially. Terga II-VII with posterolaterally well developed lobes and terga II-IX with a blunt spine postero-medially. Abdominal terga IV-V widest. Terga VIII-IX slightly laterally compressed and tectiform. Tergum X with a longitudinal ridge and posterior edge notched, posterolateral angles rounded. Cerci small, round in cross section; apex rounded, slightly projecting over apex of abdomen. Abdominal sterna smooth. Subgenital plate slightly compressed laterally, acute posteriorly, reaching apex of abdomen.

LEGS. Long, profemora compressed and curved basally. Femora and tibiae compressed laterally, with all carinae developed. Basitarsi longer than following tarsomeres combined. Tarsomeres gradually decreasing in length. Claws small.

\section{Distribution}

The species is recorded from Luzon, Benguet Province (see map Fig. 13).

Genus Capuyanus gen. nov. urn:1sid:zoobank.org:act:0885CADA-AF23-4842-B24D-3F26826E5475

\section{Type species}

Capuyanus magwilangi gen. et sp. nov.

\section{Etymology}

The genus is named after Mr Benjamin G. Capuyan, the vice-mayor of Sagada, in acknowledgement of all his help, friendship and support during our fieldwork in Sagada. 


\section{Diagnosis}

Closely related to Otraleus Günther, 1935 but easily distinguished by:

1. the strongly tapered subgenital plate in females, projecting over apex of tergum X.

2. the swollen and conical thornpads on the anal segment in males.

3. abdominal terga without well developed lobes posterolaterally.

\section{Description}

\section{Male and female}

Small and slender Necrosciinae (body length: female $47.4 \mathrm{~mm}$, male $42.6 \mathrm{~mm}$ ), apterous.

HEAD. Longer than wide, notched dorsally between antennae. Eyes circular and strongly projecting hemispherically. Antennae filiform, pedicellus shorter than scapus and round in cross section. Antennomeres narrower than pedicellus, varying in length towards apex.

Thorax. Pronotum granulose; behind anterior edge a transverse groove and a longitudinal groove not reaching the posterior margin. Posteromedially with a small granule or tubercle. Mesonotum elongated and granulose, with a tubercle posteromedially. Metanotum granulose, medially with a spinose tubercle subapically.

ABDOMEN. Median segment granulose and with a blunt tubercle or spine posteromedially. Terga II-VIII with a granule or blunt spine posteromedially. Females with subgenital plate slightly elongated and strongly tapered, projecting over apex of abdomen. Males with thompads, strongly conically swollen

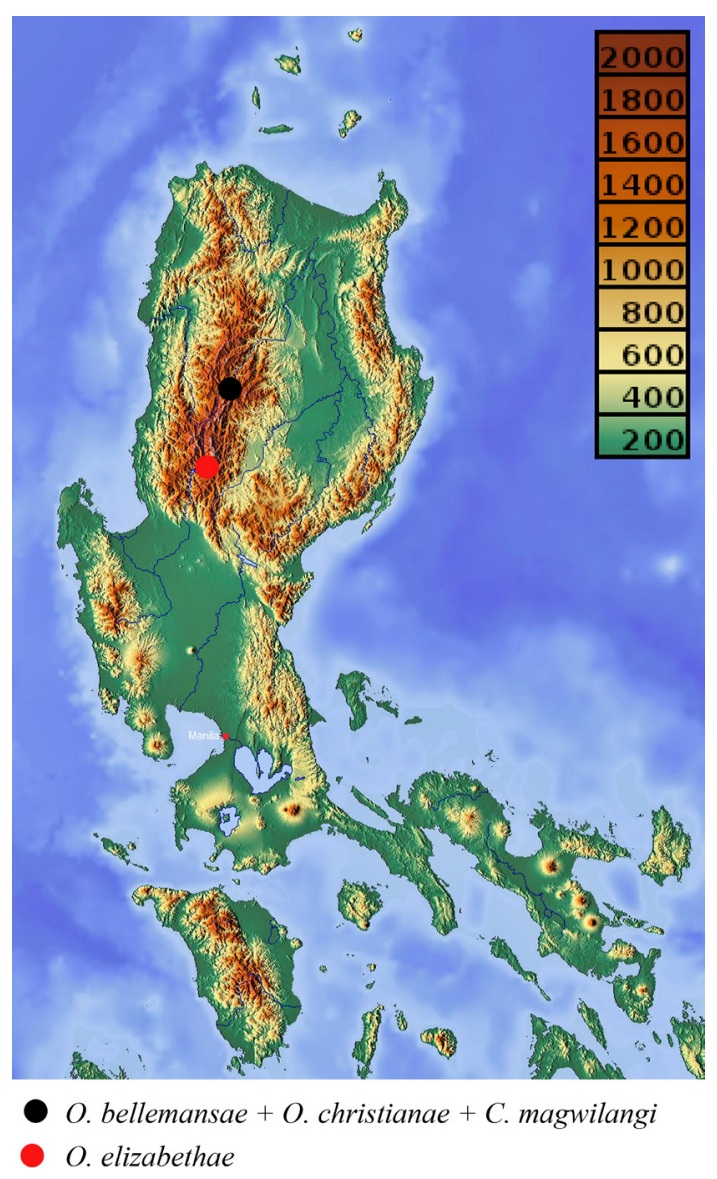

Fig. 13. Otraleus spp. and Capuyanus magwilangi sp. nov. Distribution map in Luzon. 
Table 5. Measurements (mm) of Capuyanus magwilangi $\mathrm{sp}$. nov. $\mathrm{HT}=$ holotype; $\mathrm{PT}=$ paratype.

\begin{tabular}{lcc}
\hline & HT ㇒ $^{\text {P }}$ & PT \\
\hline Body & 42.6 & 47.4 \\
Head & 2.8 & 4.2 \\
Pronotum & 2.6 & 3.0 \\
Mesonotum & 9.4 & 10.4 \\
Metanotum & 2.6 & 3.1 \\
Median segment & 2.4 & 2.7 \\
Profemora & - & 14.4 \\
Mesofemora & 11.6 & - \\
Metafemora & 16.8 & 15.3 \\
Protibiae & - & 15.1 \\
Mesotibiae & 11.6 & - \\
Metatibiae & 18.4 & 16.8 \\
\hline
\end{tabular}

and armed with spines. Vomer well developed, visible as a triangular black, flattened spine. Cerci small, round in cross section; apices rounded, projecting over apex of abdomen.

LEGs. Long compared to body, profemora compressed and curved basally. Femora and tibiae compressed laterally, with all carinae developed. Tarsomeres gradually decreasing in length. Claws small.

Capuyanus magwilangi gen. et sp. nov. urn:1sid:zoobank.org:act:CB199024-1835-4FCE-A9A4-18FC375D444F

Figs 13, 14B, 15-16

\section{Etymology}

The species epithet is given after Ir. Andrew Magwilang, head of the National Commission on Indigenous People bureau in Sagada, in acknowledgement of all his help, friendship and support during our fieldwork in Sagada.

\section{Type material}

Holotype

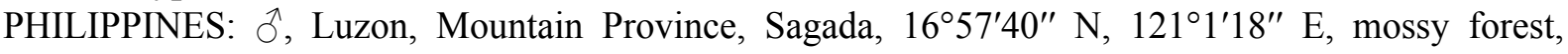
15 Apr. 2014, Mission Leopold III funds, Constant J., Bresseel J. and co. leg. (RBINS IG 32700).

\section{Paratype}

PHILIPPINES: 1 , same collection data as holotype (RBINS).

\section{Description}

Male (Figs 14B, 15)

MeAsurements. See Table 5.

BoDY. Uniformly brown with black markings.

HEAD. Longer than wide, notched dorsally between antennae. Notch followed by a definite median longitudinal impression. Eyes circular and strongly projecting hemispherically. Antennae slightly setose, 
projecting over apex of abdomen. Scapus and pedicellus damaged. Pedicellus shorter than scapus. Antennomeres narrower than pedicellus and varying in length towards apex.

Thorax. Pronotum granulose, about as long as head. Posteriorly of anterior edge, a transverse groove and a longitudinal groove not reaching posterior edge. Just before centre, a second transverse incurved impression and a minute, circular impression anteriorly of transverse impression. Posteromedially with a small tubercle. Mesonotum elongated and wrinkled, with a small tubercle posteromedially, at two thirds of the length with two oval, black markings. Metanotum granulose, about same length as median segment. Medially with a spinose tubercle subapically.

ABDomen. Median segment granulose, with a spinose tubercle posteromedially. Terga II-VIII with a spinose tubercle posteromedially, decreasing in size towards posterior. Tergum IX slightly laterally compressed, with a hump posteromedially. Tergum $\mathrm{X}$ with posterior edge slightly incurved, posterolateral angles rounded. Ventral part of posterolateral portion of tergum X strongly swollen and conical; cone covered with small black spines. Cerci small, round in cross section; apices rounded, projecting over apex of abdomen. Abdominal sterna smooth. Vomer well developed, visible as a triangular black, flattened spine with paler apex. Poculum slightly flattened, narrowing towards posterior; apex slightly rounded, reaching apex of tergum IX.

LEGs. Fore legs missing. Other legs long when compared to body. Femora and tibiae compressed laterally, with all carinae developed, slightly widening towards posterior. Tarsomeres gradually decreasing in length. Claws small.

Female (Fig. 16)

Measurements. See Table 5.

BoDY. Uniformly brown with black markings.

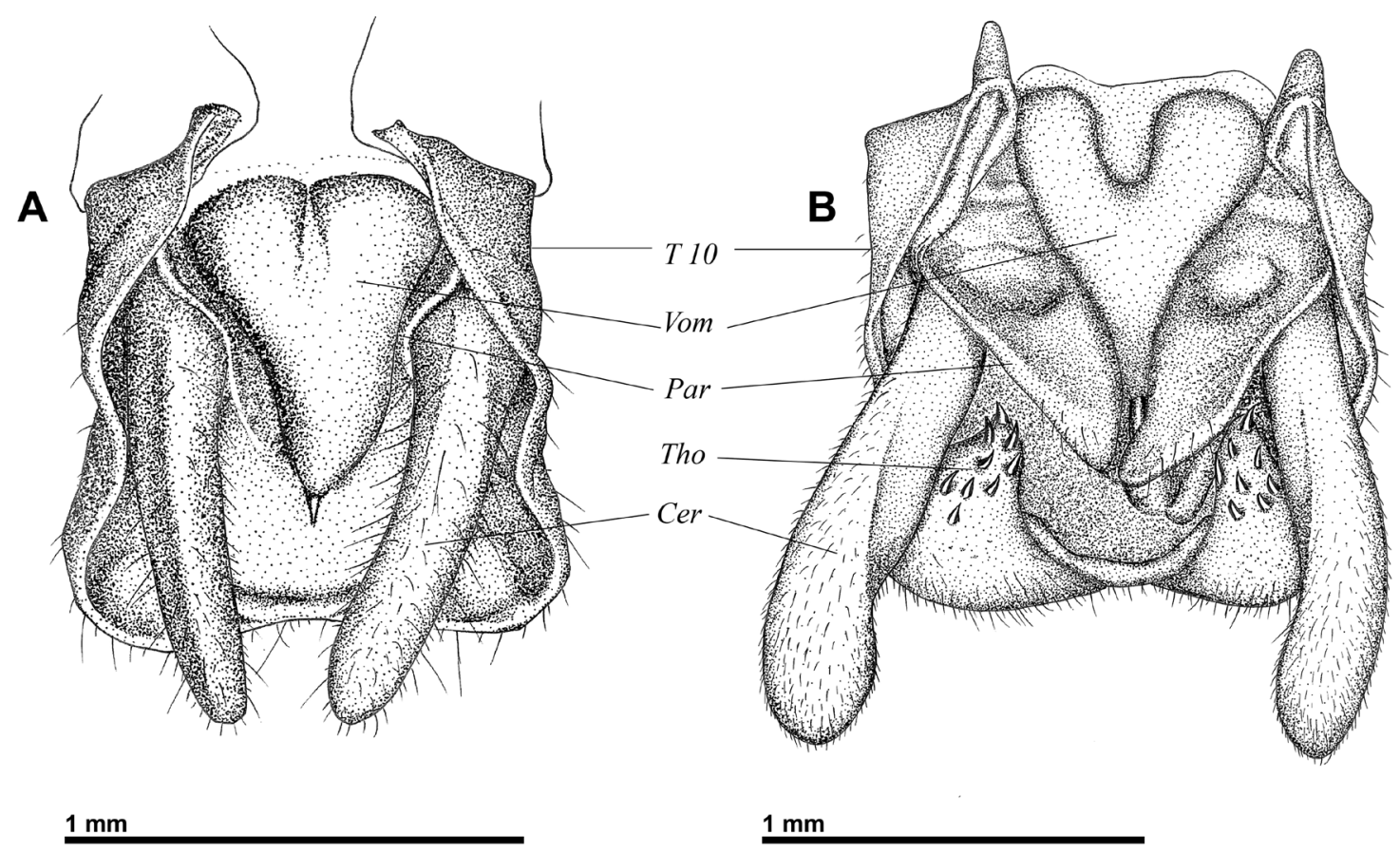

Fig. 14. Male terminalia, ventral view. A. Otraleus elizabethae sp. nov. B. Capuyanus magwilangi gen. et sp. nov. Abbreviations: $C e r=$ cercus; $P a r=$ paraproct; $T 10=$ abdominal tergum 10; $T h o=$ thornpad; Vom $=$ vomer. 

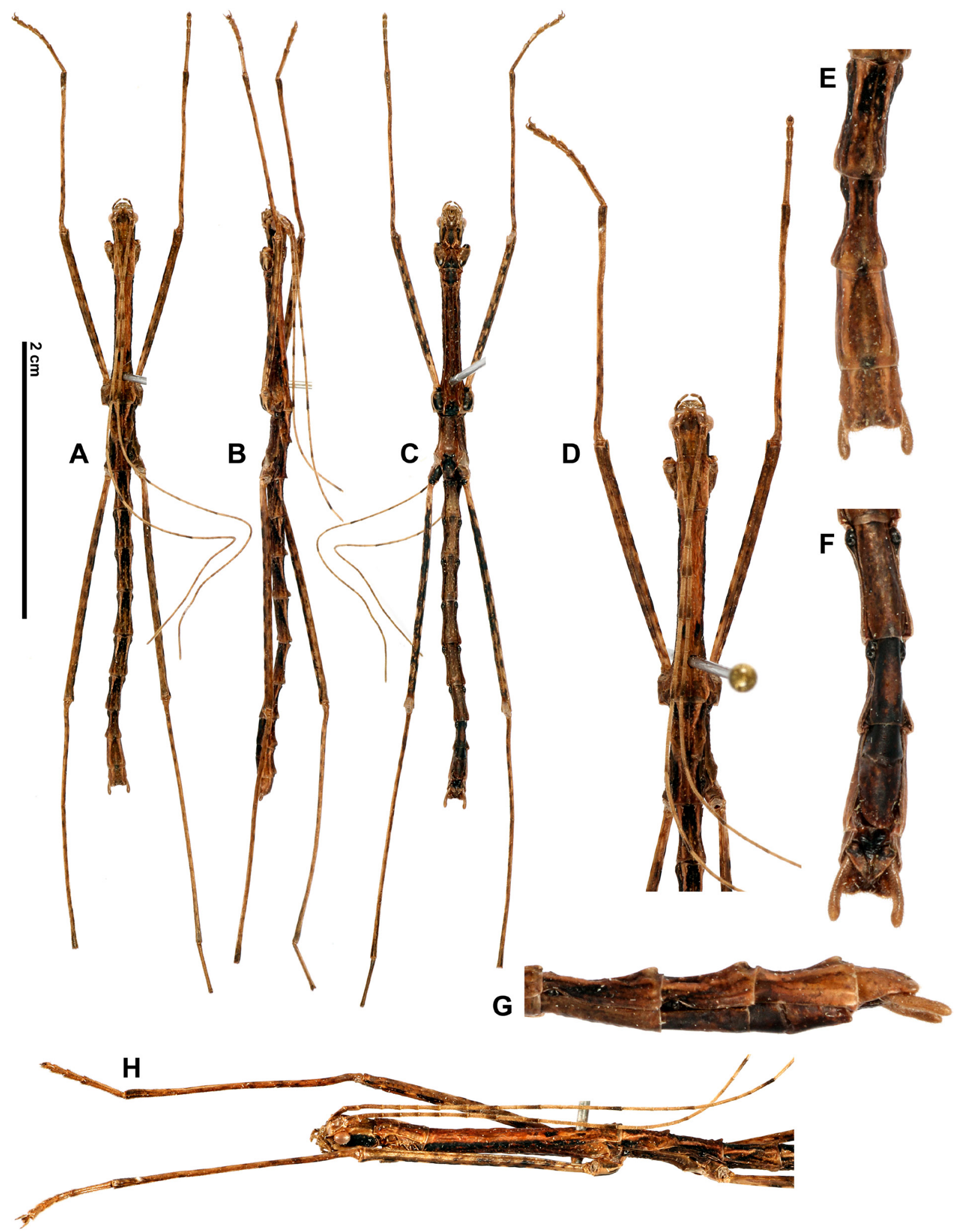

Fig. 15. Capuyanus magwilangi gen. et sp. nov., Ô, holotype. A. Habitus, dorsal view. B. Habitus, lateral view. C. Habitus, ventral view. D. Anterior part of body, dorsal view. E. Apex of abdomen, dorsal view. F. Apex of abdomen, ventral view. G. Apex of abdomen, lateral view. H. Anterior part of body, lateral view. D-H: not to scale. 


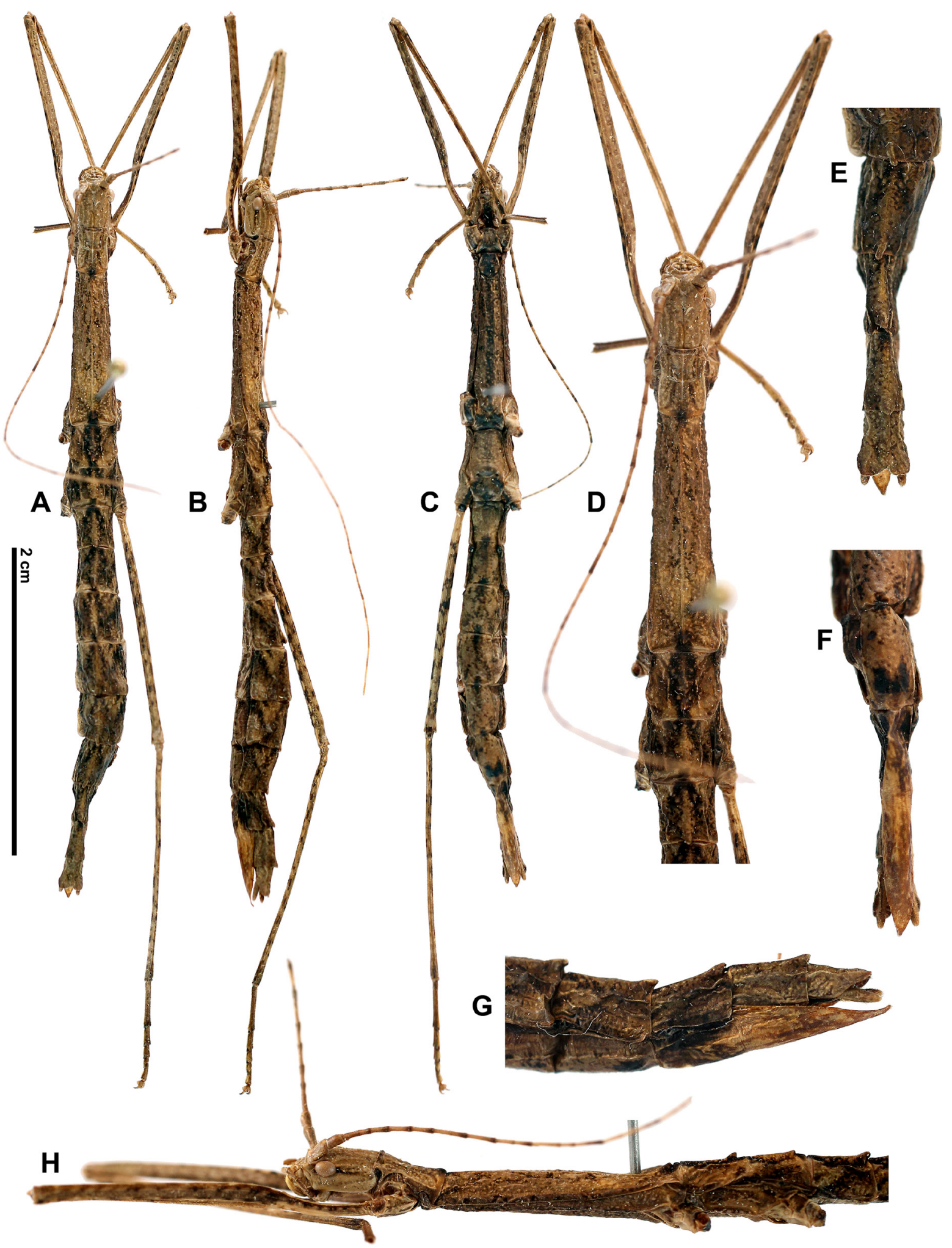

Fig. 16. Capuyanus magwilangi gen. et sp. nov.,, , paratype. A. Habitus, dorsal view. B. Habitus, lateral view. C. Habitus, ventral view. D. Anterior part of body, dorsal view. E. Apex of abdomen, dorsal view. F. Apex of abdomen, ventral view. G. Apex of abdomen, lateral view. H. Anterior part of body, lateral view. D-H: not to scale. 
HeAD. Longer than wide, notched dorsally between antennae. Behind notch, two small, black circular dots. Between eyes, a raised area. Dorsally with a fine longitudinal median line. Eyes circular and strongly projecting hemispherically. Antennae broken, scapus flattened dorsoventrally. Pedicellus shorter than scapus and round in cross section. Antennomeres narrower than pedicellus, varying in length towards apex.

Thorax. Pronotum granulose, shorter than head, with anterior edge slightly concave. Behind edge, a transverse groove and a longitudinal groove not reaching posterior granule. Pronotum slightly constricted just before centre. Centrally with a second transverse impression and a small, circular impression anteriorly of transverse impression. Posteromedially with a small granule. Mesonotum elongated and granulose, with a tubercle posteromedially. Mesonotum slightly widening towards the posterior. Metanotum about same length as pronotum. Medially with a blunt, spinose tubercle subapically. Metanotum laterally rounded, with widest part centrally.

ABDOMEN. Median segment slightly shorter than metanotum, with a blunt spine posteromedially. Terga II-IX with a blunt spine posteromedially. Abdominal terga IV-VI widest. Terga VIII-IX laterally compressed and tectiform. Tergum $\mathrm{X}$ with a longitudinal ridge and posterior edge notched; posterolateral angles rounded. Cerci small, round in cross section; apices rounded, slightly projecting over apex of abdomen. Abdominal sterna smooth. Subgenital plate slightly compressed laterally, acute posteriorly, projecting over apex of abdomen.

LEGs. Middle legs missing. Other legs long compared to body; profemora compressed and curved basally. Femora and tibiae compressed laterally, with all carinae developed. Tarsomeres gradually decreasing in length. Claws small.

\section{Distribution}

The species is recorded from Luzon, Mountain Province (see map Fig. 13).

\section{Discussion}

The present paper provides a set of original and fairly unexpected data. The genus Otraleus is recorded from the Philippine Islands for the first time, which is far from the type locality of the genus in Central Sulawesi and that of the recently described species from Mt. Kinabalu. We also describe a new, Otraleuslike genus from the same area and habitat. In the Philippines as well as in Sulawesi and Borneo, these species seem to be restricted to high altitudes in mossy forests. The rate of new species discovery in recent years, correlated with the low number of prospected locations, leads us to predict that many more taxa probably await discovery.

However, several factors impede the progress of the scientific documentation of those specialised taxa, e.g., (1) the difficulty in accessing those remote habitats, (2) the progressive reduction of the remnants of mossy forests due to wood cutting and invasion by pine trees, (3) and the too complex regulations which actually do not effectively protect the habitats and species, but instead discourage or prevent scientists from conducting the very urgent and necessary research needed in those zones.

In Sagada, we were able to conduct our research with the authorization of the elders and leaders, under the auspices of the National Commission on Indigenous People. We also noted the environmental awareness of local people who even conduct removal of pine tree seedlings to protect the mossy forest patches around the village (B. Capuyan pers. comm., Apr. 2014).

A vast field of research remains open on the Philippine Phasmida to document their distribution, lifehistory and phenology. In this scope, we strongly encourage the collaboration with local scientists and 
amateur naturalists whenever possible, as the critical key for observation of those insects is the amount of time spent in the field. Many areas and even islands of the Philippine Archipelago remain unexplored in terms of phasmids and more field work would probably also reveal more undescribed species.

\section{Acknowledgements}

We thank Mrs Nathalie Bellemans (Belgium) and Anne Lefèvre (Belgium) as well as Messrs Thierry Heitzmann (Philippines), Albert Kang (Malaysia), Paulo Ortega (Philippines), Vincent Sougnez (France) and John Vergara (Philippines) for their help, company and enthusiasm during our collecting trip in Luzon, and contributions to the present study in terms of photographs and material; Mr Oskar Conle and Mr Frank Hennemann for the kind authorization to publish their photographs of the type of Otraleus hypsimelathrus Günther, 1935; Dr Francis Seow-Choen is thanked for providing the necessary literature on Otraleus labanrataensis Seow-Choen, 2016; Mr Julien Caudron (RBINS) for the drawings of terminalia; Dr Sheryl Yap (University of the Philippines, Los Baños), Mrs Jean Bacayan, Maritess Alimurung, Matilde Gumtang (Bureau of Plant Industry, Baguio), Mr Benjamin G. Capuyan (ViceMayor, Sagada), Ir Andrew Magwilang (National Commission on Indigenous People, Sagada office), Attorney Amador P. Batay-An and Ir Mabli (National Commission on Indigenous People, Regional office, Baguio) for all their help in obtaining the collecting permits, and especially the elders and leaders of Sagada who so kindly supported our research in their ancestral grounds. This study is part of the "Exploration of the entomofauna of the Cordillera Central, Luzon, Philippines" project (J. Constant-J. Bresseel), which was sponsored by the "Fonds Léopold III pour l'exploration et la conservation de la nature" and by the Entomology Department of RBINS. Dr Jackie Van Goethem (RBINS, Leopold III Funds) and Dr Patrick Grootaert (RBINS, Entomology) are warmly thanked for their support to the project.

\section{References}

Bragg P.E. 2001. Phasmids of Borneo. Natural History Publications (Borneo), Kota Kinabalu, Sabah, Malaysia.

Bradley J.C. \& Galil B.S. 1977. The taxonomic arrangement of the Phasmatodea with keys to the subfamilies and tribes. Proceedings of the Entomological Society 79 (2): 176-208.

Günther K. 1935. Die von Gerd Heinrich 1930-32 auf Celebes gesammelten Phasmoiden. Mitteilungen aus dem Zoologischen Museum, Berlin 21 (1): 1-29.

Günther K. 1938. Orthoptera Celebica Sarasiniana. II. Phasmoidae. Verhandlungen der Naturforschenden Gesellschaft, Basel 49: 54-92.

Hennemann F.H. 1998. Ein Beitrag zur Kenntnis der Phasmidenfauna von Sulawesi. Mit einem Katalog der bisher bekanntgewordenen Arten. Mitteilungen des Museums für Naturkunde, Berlin, Zoologische Reihe 74 (1): 95-128.

Otte D. \& Brock P. 2005. Phasmid Species File. Catalog of Stick and LeafInsects of the World. 2nd edition. The Insect Diversity Association and the Academy of Natural Sciences, Philadelphia. CafePress.com.

Seow-Choen F. 2016. A Taxonomic Guide to the Stick Insects of Borneo. Natural History Publications (Borneo), Kota Kinabalu, Sabah, Malaysia.

Weems Jr. H.V. 1986. In memoriam Gerd H. Heinrich, Research Associate of the Florida State Collection of Arthropods. Florida Entomologist 69 (1): 281-283.

Zompro O. 2004. Revision of the genera of the Areolatae, including the status of Timema and Agathemera (Insecta, Phasmatodea). Abhandlungen des Naturwissenschaftlichen Vereins Hamburg (Neue Folge) 37. 
Zompro O. 2005. Catalogue of type-material of the insect order Phasmatodea, housed in the Museum für Naturkunde der Humboldt-Universität zu Berlin, Germany and in the Institut für Zoologie der MartinLuther-Universität in Halle (Saale), Germany. Deutsche Entomologische Zeitschrift 52 (2): 251-290. http://dx.doi.org/10.1002/mmnd.200410018

Manuscript received: 26 March 2016

Manuscript accepted: 7 July 2016

Published on: 27 January 2017

Topic editor: Gavin Broad

Desk editor: Kristiaan Hoedemakers and Charlotte Gérard

Printed versions of all papers are also deposited in the libraries of the institutes that are members of the EJT consortium: Muséum national d'Histoire naturelle, Paris, France; Botanic Garden Meise, Belgium; Royal Museum for Central Africa, Tervuren, Belgium; Natural History Museum, London, United Kingdom; Royal Belgian Institute of Natural Sciences, Brussels, Belgium; Natural History Museum of Denmark, Copenhagen, Denmark; Naturalis Biodiversity Center, Leiden, the Netherlands. 